\title{
0 patrimônio bibliográfico no Brasil: trajetória de leis, políticas e instrumentos de proteção legal
}

\author{
Renata Ferreira dos Santos* \\ Alcenir Soares dos Reis ${ }^{\star \star}$
}

Artículo recibido:

20 de junio de 2015

Artículo aceptado:

28 de octubre de 2016

\section{Resumen}

Este artículo presenta una visión histórica de la evolución de las leyes, las políticas y los instrumentos de protección jurídica del patrimonio bibliográfico en Brasil entre los siglos XIX al XXI. La revisión de literatura del derecho del patrimonio cultural y la legislación actual muestran que la noción de patrimonio bibliográfico se asocia con la práctica de depósito legal de libros contemporáneos y con los controles de la circulación de libros raros y antiguos. Presenta los principales instrumentos de protección jurídica del patrimonio cultural brasileño, con miras a su uso en los bienes culturales muebles de bibliográfica naturaleza.

* Universidade Federal de Ouro Preto, Brasil.

rferreirasantos@hotmail.com

** Universidade Federal de Minas Gerais, Brasil.

alcenirsoares@gmail.com

INVESTIGACIÓN BIBLIOTECOLÓGICA, vol. 32, núm. 75, abril/junio, 2018, México, ISSN: 2448-8321 pp. 223-259 
Palabras clave: Patrimonio Bibliográfico; Protección Jurídica; Brasil

Bibliographic heritage in Brazil: history of laws, policies and instruments of legal protection

Renata Ferreira dos Santos and Alcenir Soares dos Reis

\begin{abstract}
This paper offers a historical overview of the evolution of laws, policies and instruments for the legal protection of bibliographic heritage in Brazil from the nineteenth to the twenty-first century. The literature review of cultural heritage and current legislation reveal that the notion of bibliographic heritage is associated with the practice of legal deposit of current books and control of circulation of rare and antique books. The research presents the key instruments of Brazilian cultural laws, analyzing how these could be used to protect bibliographical heritage.
\end{abstract}

Keywords: Bibliographic heritage; Legal protection; Brazil

\title{
INTRODUÇÃO
}

G ste artigo apresenta parte dos resultados de uma pesquisa de mestrado em Ciência da Informação, que buscou refletir acerca da proteção legal do patrimônio bibliográfico no Brasil, a partir da atuação do Governo Federal na salvaguarda de acervo de obras raras em cidade histórica.

A pesquisa partiu do pressuposto de que o conhecimento e o acesso à informação sobre os diversos elementos constituintes da cultura brasileira são fatores fundamentais para o pleno exercício dos direitos individuais e coletivos. Nesta perspectiva, a Ciência da Informação pode contribuir para a valorização dos bens culturais móveis custodiados em arquivos, bibliotecas e museus, ao estudar o modo como os acervos destas instituições foram criados, tratados e patrimonializados por diferentes grupos sociais. Estabeleceu-se a aproximação do tema do Patrimônio Cultural e da Ciência da Informação, a partir da Biblioteconomia de Livros Raros, disciplina que se dedica a estudar a história das bibliotecas, bem como a produção, circulação, captação e acesso às fontes de informação escritas e impressas (Pinheiro, 
2009). Os questionamentos relativos à proteção legal de acervos bibliográficos raros propiciou o diálogo com o campo do Direito do Patrimônio Cultural no Brasil, o qual se dedica à defesa jurídica dos elementos materiais e imateriais portadores de valores de referência para a memória, a identidade e a ação dos diferentes grupos formadores da sociedade, por meio do estudo da legislação, doutrina e jurisprudência (Prado, 2009).

A interseção entre estes diferentes campos do conhecimento advém da constatação que a proteção de bens culturais móveis de valor bibliográfico no Brasil, está relacionada à prática do depósito legal para obras correntes e ao controle da circulação de obras raras. $\mathrm{O}$ tratamento dado à matéria no ordenamento jurídico reflete o processo de desenvolvimento da leitura, da indústria editorial e das bibliotecas neste País.

O patrimônio bibliográfico é uma modalidade do patrimônio cultural ainda pouco discutida pela sociedade brasileira, porque os livros passaram a existir em maior quantidade no território a partir do século XIX, sendo usados para educar a população, disseminar conhecimentos científicos e divulgar o País no exterior. Ao longo do século XX, as ações em prol da proteção dos bens culturais impressos se confundiram com as políticas públicas federais de promoção e acesso à cultura. Decorridas quase duas décadas do século XXI, observa-se o estímulo à candidatura de acervos ao reconhecimento de valor cultural internacional e o controle de circulação de obras raras.

$\mathrm{O}$ artigo apresenta uma retrospectiva histórica sobre a evolução de leis e políticas relacionadas ao patrimônio bibliográfico no Brasil, a partir do levantamento da legislação vigente sobre o tema e a revisão da literatura do Direito do Patrimônio Cultural. Analisa ainda os principais instrumentos de proteção legal previstos na Constituição, com vistas à defesa dos bens culturais de natureza bibliográfica.

\section{AnteCedentes históRicos}

Durante o período em que o Brasil foi colônia de Portugal (1500-1808), foram proibidas a produção e a circulação de impressos. Os livros que chegavam ao território eram importados ou contrabandeados da Europa. As bibliotecas eram privadas, de posse de uma pequena e seleta sociedade letrada, formada por membros do clero e de particulares, em sua maioria, homens brancos e ricos a serviço da Coroa ou grandes proprietários de terras.

A licença para imprimir e o incentivo a criação de bibliotecas ocorreram no período monárquico (1808-1889), após a transferência da Corte portuguesa para o Rio de Janeiro, o que propiciou o surgimento da Real Biblioteca 
e da Imprensa Régia. No âmbito das políticas de abertura do Reino do Brasil às nações estrangeiras, foi incentivada a entrada de viajantes naturalistas e de artistas a partir de 1816, com o objetivo de descrever a natureza e retratar a sociedade local. De certo modo, as missões artísticas e científicas foram as primeiras políticas culturais do Império do Brasil. No âmbito educacional, foram liberadas a criação de liceus, externatos, instituições de ensino superior e instituições científicas.

No primeiro período republicano (1889-1930) cresceram o número de escolas, de estabelecimentos editoriais e de bibliotecas públicas. Era preciso educar a população, reduzir o analfabetismo e formar mão de obra especializada para a indústria. O livro se constituiu como o principal instrumento de aprendizagem, estimulando a produção de material didático e de obras de literatura clássica em larga escala.

No regime ditatorial denominado "Estado Novo" (1930-1945), caracterizado pela intensa valorização da memória nacional, aumentaram os esforços em localizar e em reaver os primeiros registros impressos sobre o Brasil, identificados dentro e fora do País, com intuito de reescrever a história e subsidiar a pesquisa científica.

Nos governos subsequentes, sobretudo ao longo da Ditadura Militar (1964-1984), o interesse sobre o livro recaiu na edição maciça de títulos para distribuição gratuita em escolas e bibliotecas, na vigilância em torno de acervos históricos para impedir a evasão de bens culturais sem prévia autorização, a exemplo das obras de arte e dos livros raros.

A retomada da democracia teve como marco legal a promulgação da Constituição de 1988, também chamada "Constituição Cidadã", cujo art. 215 determina que o "Estado garantirá a todos o pleno exercício dos direitos culturais e acesso às fontes da cultura nacional, e apoiará e incentivará a valorização e a difusão das manifestações culturais". O texto constitucional ampliou ainda as categorias do patrimônio cultural. Neste período, foi estimulada a integralização dos serviços técnicos bibliotecários de organização e de difusão de acervos, inclusive de obras raras.

Nas três décadas seguintes, observou-se dois movimentos em torno das coleções bibliográficas raras: a prevenção contra a saída ilegal de itens para fora do País e a candidatura para reconhecimento de seu valor cultural em nível internacional. Dessa forma, a discussão em torno do patrimônio bibliográfico brasileiro esteve centrada em aspectos relativos à segurança de acervos de obras raras, a fim de evitar furtos por quadrilhas especializadas; o tratamento técnico das coleções e o intercâmbio de registros bibliográficos. O conceito e a abrangência do patrimônio bibliográfico no Brasil, só recentemente, tem sido tema de debate entre especialistas dedicados ao livro raro e ao patrimônio cultural. 


\section{O CONCEITO DE PATRIMÔNIO BIBLIOGRÁFICO NO BRASIL}

Segundo Askerud e Clement (1999: 36) as deficiências mais comuns na legislação do patrimônio cultural são as seguintes: a falta de precisão terminológica utilizada para definir bens culturais; a indulgência contraproducente sobre as penas por infração das leis e os regulamentos relativos ao tráfico ilícito; a inconsistência entre as leis e os regulamentos, quanto a sua aplicação; e a ausência de um marco institucional.

Entende-se que a proteção do patrimônio cultural requer a sua definição conceitual, o que não é uma tarefa fácil. O conceito de patrimônio cultural por si só é transversal, nômade, porque foi requalificado por diferentes áreas do conhecimento (Choay, 2006). É um conceito relativo, que se sustenta em valores subjetivos em determinado tempo (Pedraza Gracia, 2010).

A origem etimológica da palavra patrimônio vem do radical latino pater, que significa pai, genitor, progenitor (Facciolati, Forcellini e Furlanetto, 1871: v. 3:596). Associado ao verbo moneo se traduz como fazer saber, fazer recordar (Cunha, 2010). Sendo assim, patrimônio é literalmente o que recorda ao pai (Baez, 2006: 24).

A denominação mais antiga de patrimônio foi dada pelos romanos, que o chamavam res, no sentido de coisa. $\mathrm{Na}$ Roma antiga, patrimonium significava todas as "coisas" privadas e particulares (Castriota, 2009: 42). O conceito de patrimônio se tornou sinônimo de riqueza financeira e moral no século XV (Palazzi, 1946).

Em língua portuguesa, o significado de patrimônio manteve a noção de propriedade oriunda do Direito romano, relativo aos bens de qualquer natureza adquiridos ou herdados sucessivamente na mesma família (Rodrigues, 2008). No século XVIII, passou a considerar também os bens provenientes da mãe e da Igreja (Bluteau, 1720: v. 6:323). O significado mais abrangente de patrimônio passou a ser adotado a partir do século XIX, indicando ainda os bens temporais adquiridos por qualquer título e uma porção determinada de bens para sustentação de qualquer ordenado (Vieira, 1874: v. 4:705).

$\mathrm{O}$ uso moderno da palavra patrimônio englobou o seu valor social enquanto o conjunto de bens materiais ou morais, pertencentes a uma pessoa, instituição ou coletividade (Michaelis e Weiszflog, 1998: 1570). Recentemente, a expressão patrimônio cultural passou a abranger não só aspectos do conceito de propriedade, como também a forma que o Estado atua na preservação da memória coletiva (Rodrigues, 2008), inclusive os instrumentos adotados para sua proteção legal. Assim, patrimônio cultural compreende: “(...) o conjunto de bens culturais ou naturais, de valor reconhecido por determinada localidade, região, país, ou para a humanidade, e que ao se 
tornar(rem) protegido(s), como por exemplo, pelo tombamento, devem ser preservado(s) para o uso fruto de todos os cidadãos" (Ferreira, 2009: 1508).

No entanto, a indefinição terminológica no campo do patrimônio cultural se estende a suas diferentes modalidades e aos seus respectivos bens constituintes. $\mathrm{O}$ conjunto de bens culturais de natureza bibliográfica é comumente denominado "patrimônio bibliográfico". No âmbito dos Estados, patrimônio bibliográfico nacional é o conjunto das espécies bibliográficas, acumuladas ao longo dos séculos e que vinculam a herança cultural de um povo, seja qual for o seu suporte (Faria e Pericão, 2008: 468). Nota-se que a definição de patrimônio bibliográfico está relacionada com o processo de produção e de apropriação do livro em diferentes regiões, a história cultural e política de uma sociedade, e com o ordenamento jurídico de cada país.

$\mathrm{Na}$ Europa, o conceito de patrimônio bibliográfico foi elaborado a partir da noção de bens culturais móveis proposta pela Organização das Nações Unidas para a Educação Ciência e Cultura (UNESCO). A menção deste conceito em textos legais reflete o processo de formação e de desenvolvimento das coleções de livros em cada nação, com o claro objetivo de indicar quais os bens culturais necessitavam de maior atenção jurídica do Estado para coibir o trafico ilícito, facilitado em situações de conflito armado e pela abertura das fronteiras entre os blocos econômicos na região.

Na Espanha, a Lei n ${ }^{\circ}$ 16, de 25 de junho de 1985, mais conhecida como Ley del Patrimonio Documental Histórico Español ou LPHE dedicou o capítulo $\mathrm{V}$ ao patrimônio documental e bibliográfico, ou seja, "os documentos e os livros componentes ou não de acervos de arquivos ou bibliotecas, incluídos neles todas as formas de expressão em linguagem natural ou convencional ou outra qualquer expressão gráfica, sonora ou em imagem”. Tais bens são disciplinados pelos artigos 48, 49 e 50. Neste último a LPHE esclarece que fazem parte do patrimônio bibliográfico "as bibliotecas e coleções bibliográficas públicas, as obras literárias, históricas, científicas e artísticas editadas até 1958, que possuam pelo menos três exemplares”. A data-limite de 1958 remete a criação do depósito legal espanhol.

Na França, a Lei no 92-546, de 20 de junho de 1992, estendeu o depósito legal a todos os documentos impressos, iconográficos, gráficos e etc. A Lei de 31 de dezembro de 1992 adaptou a legislação francesa referente à proteção do patrimônio cultural às normas da Comunidade Europeia, com base nos Acordos de Schegen, que promoveu a livre circulação de pessoas, bens e mercadorias pelo continente (Rodrigues, 2008). De acordo com a Charte du Conseil Supérieur des Bibliotheques, o patrimônio bibliográfico francês constitui "o conjunto de coleções bibliográficas nacionais formadas 
através do depósito legal e de livros raros, antigos e preciosos" (Mouren, 2012: 26).

Em Portugal, a Lei n 107 , de 8 de setembro de 2001, ou Lei de Bases do Patrimônio Cultural, também conhecida como LBPC ou Lei de Bases, estabeleceu os pilares da política e do regime de proteção e valorização do patrimônio cultural. A LBPC define o patrimônio bibliográfico como "as espécies, as colecções e os fundos bibliográficos que se encontrem, a qualquer título, na posse de pessoas colectivas públicas, independentemente da data em que foram produzidos ou reunidos, bem como as colecções e os espólios literários”. A norma trata o patrimônio bibliográfico como uma modalidade de regime especial, que abrange coleções públicas e privadas, estabelece os conceitos de obras raras, os princípios de inventário e os incentivos fiscais para sua proteção. A Lei de Bases orienta ainda para a inventariação de manuscritos notáveis ou de impressos raros, a classificação de livros de interesse nacional ou de interesse público.

No Brasil, a legislação em vigor ainda não foi capaz de conceituar todas as categorias de bens culturais, e consequentemente, todas as modalidades de patrimônio cultural, porque nem todos os elementos da cultura são reconhecidos pelo Estado como bens de interesse público. Dentre os fatores que colaboram para esta lacuna estão o processo de formação da nação brasileira, suas dimensões continentais e a grande diversidade cultural de seu povo. A leitura das normas nacionais sobre a proteção do livro como bem cultural, revela que a noção de patrimônio bibliográfico está em processo de construção e que até o momento está associada à prática do depósito legal para obras correntes e ao controle da circulação de obras raras e antigas.

$\mathrm{Na}$ ausência de um conceito de patrimônio bibliográfico, amplamente aceito e difundido no Brasil, a presente pesquisa considerou esta modalidade de patrimônio como o conjunto de bens culturais de natureza bibliográfica (manuscritos, incunábulos, livros, periódicos, mapas, folhetos e obras de referência), cuja raridade a eles atribuída reconhece o seu valor para à história e à memória deste País ao longo dos séculos, os quais foram elaborados, publicados e utilizados por seus cidadãos dentro do próprio território. Também integram o patrimônio bibliográfico nacional as criações impressas que tratam do Brasil, elaboradas neste País por autores estrangeiros e publicadas no exterior, bem como as criações impressas de origem estrangeiras, incorporadas aos acervos das primeiras bibliotecas brasileiras, que colaboraram diretamente para o desenvolvimento intelectual desta nação.

Veremos a seguir como o regime jurídico brasileiro trata a matéria da proteção do patrimônio cultural, com foco na modalidade do patrimônio bibliográfico. 


\section{Normas legais E POLÍticas CUlTURAIS RELACIONADAS AO PATRIMÔNIO BIBLIOGRÁFICO NO BRASIL}

As tensões políticas e sociais ao longo da história do Brasil influíram no surgimento de normas legais para a proteção do patrimônio cultural e suas diferentes modalidades. Com o patrimônio bibliográfico não foi diferente. As políticas culturais de promoção da leitura, de acesso a bibliotecas públicas e de resgate das fontes sobre a história do País se confundiram com os propósitos e as necessidades de proteção jurídica dos bens impressos.

Para facilitar a compreensão do processo de evolução das normas, políticas e instrumentos de proteção legal do patrimônio bibliográfico no Brasil, estabeleceu-se recortes temporais de acordo com os regimes políticos do País entre os séculos XIX e XXI. O primeiro período (1847-1907) abrange a transição do regime monárquico para o republicano, desde o final do I Reinado até a I República. O segundo período (1930 a 1945) se refere ao Estado Novo, regime ditatorial no qual foram implantadas as principais ações de proteção do patrimônio cultural ainda em vigor. O terceiro período (1946 a 1988) compreende a alternância entre a restauração do regime democrático, contido pela Ditadura Militar a partir de 1964, ate a reabertura política na década de 1980. O quarto período (1989 a 2015) abarca as ações posteriores à promulgação da nova Constituição até os dias atuais.

\section{0 periodo: 1847-1907}

A decisão de recolher e preservar a produção de materiais impressos no Brasil ocorreu no I Reinado, com as atividades da Biblioteca Nacional para o controle bibliográfico, especificamente à prática do depósito legal. O Decreto Legislativo $\mathrm{n}^{\circ} 433$ de 3 de julho de 1847, obrigava os impressores a remeter um exemplar de todas as obras produzidas nas suas tipografias, respectivamente na Corte à Biblioteca Nacional e nas Províncias à Biblioteca da Capital. Assim, a tarefa de salvaguarda da produção da literatura impressa era compartilhada por bibliotecas instaladas em diferentes pontos do território, com vistas a conhecer e controlar o que era publicado em todo o Império.

As primeiras iniciativas de proteção do que mais tarde viria a constituir o patrimônio cultural não contemplaram os livros, mas inseriram a biblioteca como o lugar de guarda das informações impressas em monumentos históricos. O Aviso de 13 de dezembro de 1855 do ministro do Império, Conselheiro Luiz Pereira de Couto Ferrraz, ordenava aos Presidentes da Província o envio de uma cópia das coleções de epigrafia de seus respectivos governos à Biblioteca Nacional e ao diretor de obras públicas da Corte o 
cuidado na reparação dos monumentos, a fim de não destruir as inscrições neles gravadas (Miranda, 2012: 195-215). Em 1885, o chefe da Seção de Manuscritos da Biblioteca Nacional, Alfredo do Vale Cabral, percorreu as províncias da Bahia, Alagoas, Pernambuco e Paraíba, a fim de recolher a epigrafia dos monumentos da região (Malhano, 2002).

Após a Proclamação da República, a obrigatoriedade do depósito legal passou a ser normatizada pelo Decreto n ${ }^{\circ} 1.825$, de 20 de dezembro de 1907, revisado pela Lei n 10.994 , de 14 de dezembro de 2004. Apesar de não tratar especificamente da proteção de bens culturais, mas sim da formação de um repositório da memória intelectual impressa, o Decreto 1.825/1907 é indicado nos compêndios de legislação sobre patrimônio cultural como a primeira norma de defesa do patrimônio bibliográfico brasileiro (Paiva e Miranda, 2011; Câmara dos Deputados, 2013).

\section{$2^{\circ}$ periodo: $1930-1945$}

$\mathrm{Na}$ verdade, a primeira proposta de proteção do patrimônio histórico e artístico que efetivamente citou os bens culturais de natureza bibliográfica foi o Projeto de Lei apresentado pelo deputado José Wanderley de Araújo Pinho (1890-1967) ao Congresso Nacional em 25 de agosto de 1930. O texto destacava os bens imóveis e móveis como elementos representativos da cultura do País e a necessidade de intervenção do Estado para a proteção dos mesmos sempre que necessário. $\mathrm{O}$ art. $4^{\circ}$ incluía entre os bens móveis os livros raros ou antigos ou incunábulos, códices e manuscritos de valor lítero-histórico ou artístico (Ministério da Educação e Cultura, 1980). No entanto, o projeto não chegou a ser votado devido à dissolução do Parlamento com a Revolução de 1930.

No Estado Novo, o Governo Federal procedeu ao inventário dos bens culturais mais significativos para a nação, à criação de instituições especializadas e à elaboração de normas para a gestão do patrimônio histórico e artístico, principalmente pela atuação do Ministério da Educação e Saúde Pública (MESP). ${ }^{1}$ A busca pelas primeiras fontes bibliográficas para reescrever a história nacional promoveu o resgate de obras raras sobre o Brasil, sobretudo de autoria dos viajantes naturalistas ou de escritores brasileiros radicados na

1 Criado pelo Decreto n ${ }^{\circ} 19.402$, de 14 de novembro de 1930, teve sua denominação alterada para Ministério da Educação e Cultura pela Lei no 1.920 , de 25 de julho de 1953, devido a implantação do Ministério da Saúde. Entre as décadas de 1930 e 1940, o MESP congregava dois grupos de instituições: de educação escolar (universidades, colégios e liceus federais) e de educação extra-escolar (Instituto Nacional do Livro, Serviço do Patrimônio Histórico e Artístico Nacional, Serviço Nacional de Teatro, Serviço de Radiodifusão Educativa, Casa Rui Barbosa, Biblioteca Nacional, Museu Histórico Nacional e Museu Nacional de Belas Artes). 
Europa. Muitas destas obras nunca chegaram a integrar os acervos das bibliotecas brasileiras ou foram levadas para o exterior sem controle, e nunca mais retornaram.

Com intuito de reaver ou adquirir títulos raros e inéditos, foi promulgado o Decreto ${ }^{\circ}$ 21.451, de 30 de maio de 1932, que autorizava a aquisição direta, por parte do MESP, junto aos editores ou a particulares, no País ou no estrangeiro, das publicações técnicas e científicas ou de edições de obras raras já esgotadas. O Decreto $\mathrm{n}^{\circ} 22.633$, de 12 de abril de 1933, tornava extensiva a mesma determinação ao Ministério da Agricultura.

Os dois decretos relacionavam-se com a Reforma do Ensino Superior, implantada em 1933, na qual várias escolas e faculdades autônomas foram absorvidas pela União e subordinadas a seus ministérios. Os estabelecimentos de ensino federal assumiram a missão de desenvolver o País, através do incentivo à pesquisa para a indústria e a agricultura, o que justificava a aquisição de obras raras, principalmente dos primeiros tratados sobre a fauna, a flora e os recursos minerais do território. Portanto, as obras raras para efeito dos decretos $21.451 / 32$ e 22.633/33 são as edições príncipes sobre a natureza e a sociedade brasileira, aquelas de interesse para os estudos de História, Letras, sobretudo para as Ciências físicas e naturais.

Pode-se aferir que as primeiras políticas e normas nacionais para a proteção do patrimônio bibliográfico surgiram com a criação do Departamento de Recreação e Cultura da Cidade de São Paulo (DCRSP), em 1935, cujo primeiro diretor foi o escritor, poeta e compositor Mário de Andrade (18931945). O Departamento incluiu a Divisão de Bibliotecas, sob a direção do bibliotecário e bibliófilo Rubens Borba de Moraes (1899-1986), responsável pela biblioteca infantil, biblioteca brasiliana, bibliotecas municipais e bibliotecas circulantes (Calabre, 2009: 70).

$\mathrm{Na}$ época, Mário de Andrade trabalhava com o prefeito Paulo Duarte na elaboração de um projeto de lei estadual para a proteção do patrimônio histórico e artístico. O I Congresso Brasileiro de Proteção à Natureza, realizado no Rio de Janeiro, propunha a criação de um serviço técnico especial de monumentos nacionais, concretizado por meio da influência do historiador Luiz Camillo de Oliveira (1904-1953), que sugeriu ao então ministro da Educação e Saúde Pública, Gustavo Capanema (1900-1985), que convidasse Mário de Andrade para redigir um plano geral deste órgão, com bases nos projetos anteriores relacionados ao tema.

O anteprojeto elaborado por Mário de Andrade para a criação do Serviço do Patrimônio Histórico e Artístico Nacional foi entregue a Capanema em 24 de março de 1936. O documento evidencia que a proximidade do poeta com Rubens Borba de Moraes colaborou para a inclusão das coleções 
bibliográficas na categoria $\mathrm{Da}$ arte histórica, isto é, todas as manifestações que refletem, contam, comemoram o Brasil e a sua evolução natural (Ministério da Educação e Cultura, 1980). Dentre as manifestações estava a brasiliana, ${ }^{2}$ ou seja, o conjunto de todo e qualquer impresso que se refira ao Brasil, de 1850 para trás, todo manuscrito referente ao Brasil, velho de mais de 30 anos, se inédito, e de 100 anos, se estrangeiro e já publicado em meios tipográficos (Ministério da Educação e Cultura, 1980).

No entanto, a proposta de criação de um órgão dedicado ao patrimônio só se efetivou com a promulgação da Lei n ${ }^{\circ}$ 278, de 13 de janeiro de 1937, que dava nova organização ao Ministério da Educação e Saúde Pública, oficializava a criação do Serviço do Patrimônio Histórico e Artístico Nacional $(\text { SPHAN })^{3}$ e do seu Conselho Consultivo. Em 10 de novembro um golpe de Estado dissolveu o Congresso Nacional e uma nova Constituição foi promulgada. A Carta Magma de 1937, incluía disposição mais vigorosa em defesa do patrimônio histórico e artístico, com a divisão de responsabilidades entre a União, os Estados e os Municípios. Todavia, o novo texto constitucional estava mais centrado no entorno dos monumentos e dos edifícios históricos, do que nos bens culturais móveis:

Art. 134 - Os monumentos históricos, artísticos e naturais, assim como as paisagens ou os locais particularmente dotados pela natureza, gozam da proteção e dos cuidados especiais da Nação, dos Estados e dos Municípios. Os atentados contra eles cometidos serão equiparados aos cometidos contra o patrimônio nacional. (Constituição, 1937)

Em seguida, o anteprojeto de Mário de Andrade foi revisto pelo advogado Rodrigo de Mello Franco (1898-1969), com base na legislação francesa e americana sobre o tema aprovadas em 1935 e o Pacto Roerich, tratado internacional para a proteção das instituições artísticas e científicas e dos monumentos históricos, ao qual o Brasil era signatário. O novo texto aprovado

2 Brasiliana foi o termo proposto por Rubens Borba de Moraes para designar a coleção de livros sobre o Brasil impressos entre 1504 (data do primeiro livro sobre o País) e 1900; e os livros escritos por brasileiros durante o período colonial (das primeiras manifestações literárias) até 1800 . (Moraes, 2010).

3 É a primeira instituição da América Latina dedicada à proteção do patrimônio cultural. Recebeu diferentes denominações ao longo dos anos, que se referem às mudanças de subordinações administrativas: Serviço do Patrimônio Histórico e Artístico Nacional (SPHAN) 19371945; Diretoria do Patrimônio Histórico e Artístico (DPHA) 1946-1970, ambas subordinadas ao Ministério da Educação; Instituto do Patrimônio Histórico e Artístico Nacional (IPHAN) 1970-1979, vinculado ao Ministério da Cultura; Secretaria do Patrimônio Histórico e Artístico Nacional (SPHAN) 1979-1990, subordinada ao Ministério da Educação e Cultura; Instituto Brasileiro do Patrimônio Cultural (IBPC) 1990-1994; novamente IPHAN desde 1994, vinculado ao Ministério da Cultura. 
e promulgado pelo Decreto-Lei n ${ }^{\circ} 25$, de 30 de novembro de 1937, que organizava a proteção do patrimônio histórico e artístico nacional instituía o SPHAN como órgão responsável pela sua execução. Os bens culturais móveis e imóveis foram considerados patrimônio a partir dos valores excepcionais para a cultura e memória nacional:

Art. $1^{\circ}$ Constituem o patrimônio histórico e artístico nacional o conjunto dos bens móveis e imóveis existentes no país e cuja conservação seja de interêsse público, quer por sua vinculação a fatos memoráveis da história do Brasil, quer por seu excepcional valor arqueológico ou etnográfico, bibliográfico ou artístico.

Nota-se que os bens de valor bibliográfico são citados, mas não são caracterizados. O DL 25/37, também conhecido como "Lei do tombamento", instituiu este ato administrativo como o principal instrumento de proteção jurídica de bens culturais, principalmente os bens imóveis (edifícios históricos, monumentos e templos religiosos). A forma de acautelamento prevista para os bens culturais móveis, inclusive sua caracterização geral, foram citadas nas disposições gerais em virtude da obrigatoriedade de registro especial para os comerciantes de obras de arte, manuscritos e livros antigos no SPHAN:

Art. 26. Os negociantes de antiguidades, de obras de arte de qualquer natureza, de manuscritos e livros antigos ou raros são obrigados a um registro especial no Serviço do Patrimônio Histórico e Artístico Nacional, cumprindo-lhes outrossim apresentar semestralmente ao mesmo relações completas das coisas históricas e artísticas que possuírem.

O enfoque e os limites do DL 25/37 influenciaram a atuação do SPHAN nos seus primeiros trinta anos de funcionamento, os quais foram marcados pela prioridade de proteção de bens culturais de valor histórico e artístico excepcional produzido no período colonial, com predominância dos elementos criados no século XVIII. Esse patrimônio compreendia, basicamente, os bens imóveis (igrejas, palácios de governo, construções militares e grandes residências) e os bens móveis integrados a estas edificações (obras de arte, sobretudo arte sacra, mobiliários e objetos de decoração), nas principais cidades coloniais.

As iniciativas de proteção do restante de bens culturais móveis foram atribuídas às demais instituições subordinadas ao Ministério da Educação, que tinham a missão didática de propagar a história nacional, sendo que duas possuem especial valor para a noção de patrimônio bibliográfico no 
Brasil: o Instituto Nacional do Livro (INL) e o Conselho Nacional de Cultura (CNC).

O INL foi criado pelo Decreto-Lei no 93, de 21 de dezembro de 1937, com o objetivo de elaborar a Enciclopédia Brasileira e o Dicionário da Língua Nacional; ${ }^{4}$ editar obras raras ou preciosas de grande interesse para a cultura nacional; apoiar a publicação de livros nacionais; facilitar a importação de livros estrangeiros e expandir o número de bibliotecas públicas. O Instituto Nacional do Livro exerceu um importante papel de divulgação de acervos detentores de livros raros e de registro do desenvolvimento de bibliotecas em todo o País, por meio da publicação do Guia das bibliotecas brasileiras, entre as décadas de 1940 e 1960. Entretanto, o INL recebeu várias críticas quanto ao seu propósito e o alcance de suas ações, sendo extinto no governo Collor em 1990.

O Conselho Nacional de Cultura criado pelo Decreto-Lei $n^{\circ}$ 526, de 1 de julho de 1938, incluía dentre suas áreas de atuação a conservação do patrimônio cultural (histórico, artístico, documental, bibliográfico e etc.). O CNC colaboraria para divulgar os primeiros livros sobre o País, mas não para consagrá-los como o patrimônio bibliográfico nacional. Dessa forma, a divisão de responsabilidades entre as instituições federais e a definição de prioridades para a defesa do patrimônio histórico-cultural, permaneceram inalteradas até o fim do Estado Novo em 1945.

\section{3o periodo: 1946-1988}

O novo período democrático teve como marco legal a promulgação da Constituição de 1946, pela qual os bens culturais da nação - obras, monumentos e documentos de valor histórico e artístico, bem como os monumentos nacionais, as paisagens e os locais de particular beleza - passaram a ser objeto de proteção do poder público (Miranda, 2006).

O texto constitucional reflete a influência que a Unesco, criada em 1945, passou a exercer no ordenamento jurídico dos seus estados-membros, para a proteção do patrimônio cultural. Isso se deve ao fato do tratado constitutivo da entidade, da qual o Brasil é membro, reconhecer a necessidade da preservação e proteção do patrimônio universal dos livros, obras de arte e monumentos de interesse histórico ou científico (Silva, 2003). Porém, a adesão dos estados-membros às convenções e às recomendações da Unesco não são garantias de ações práticas para proteção legal de todas as modalidades do patrimônio cultural. 
Este foi o caso do texto final da Convenção sobre a Proteção de Bens Culturais em Caso de Conflito Armado, realizada pela Unesco, em Haia (Suíça), em 1954. Este tratado foi o primeiro a empregar a expressão bens culturais, os quais foram divididos em três categorias: bens móveis ou imóveis; edifícios; e centros que contêm monumentos. Destaca-se que entre os bens da primeira categoria foram citados os manuscritos, os livros e as coleções bibliográficas de interesse histórico e artístico (UNESCO, 1954). A Convenção de Haia foi ratificada pelo Brasil através do Decreto $\mathrm{n}^{\circ} 44.851$, de 11 de novembro de 1958, mas não alcançou grandes efeitos jurídicos.

A principal mudança no tratamento legal dado aos bens culturais móveis no País ocorreu após a Recomendação sobre medidas destinadas a proibir e impedir a exportação, a importação e a transferência de propriedade ilícita de bens culturais, aprovada na Conferência Geral da Unesco, realizada em Paris, em 1964. A adesão do Brasil a esta recomendação resultou na promulgação da Lei $n^{\circ} 4.845$, de 19 de novembro de 1965, que proibia a saída, para o exterior de obras de arte e ofícios produzidos no País até o fim do período monárquico. Embora muitas obras impressas nesta época possuíssem pranchas e mapas que constituem verdadeiras obras de arte, para os efeitos da Lei 4.845/65 foram considerados apenas os trabalhos artísticos avulsos.

Internamente, as normas e políticas culturais em torno do livro foram redefinidas com a intenção de controlar a produção bibliográfica do País a partir do Decreto n 3.746 , de 14 de junho de 1966, que determinava a remessa de documentos gráficos e audiovisuais à Biblioteca Nacional no Rio de Janeiro e à Biblioteca da Câmara dos Deputados em Brasília. Este dispositivo ampliava a abrangência do depósito legal para além de livros e periódicos, como os anúncios e bilhetes postais, álbuns e partituras musicais, estampas, gravuras sobre madeira, metal ou outra substância, mapas, plantas, cartazes, selos, medalhas e numismáticas (Fonseca, 1972: 12). O Decreto 3.767/66 foi substituído pelo Decreto-Lei no 824, de 5 de setembro de 1969, que atribuiu também ao Instituto Nacional do Livro a tarefa de depositário de publicações. Assim, o Brasil passou a contar com duas normas e com duas agencias de depósito legal, a Biblioteca Nacional e o INL, até a extinção deste último (Campello, 2006).

Pouco depois, o antigo Conselho Nacional de Cultura foi transformado em Conselho Federal de Cultura (CFC), pelo Decreto-Lei n ${ }^{\circ} 74$, de 24 de novembro de 1966, com o objetivo de organizar o setor cultural e elaborar o Plano Nacional de Cultura. O órgão era dividido em quatro câmaras: Artes, Letras, Ciências Humanas e Patrimônio Histórico e Artístico Nacional (Maia, 2010-2011: 63). Nesta última, além do patrimônio edificado, também eram objetos de convênios a restauração e a proteção dos acervos 
documentais e bibliográficos (Calabre, 2009: 70). Dentre suas ações estavam o plano de incentivo às biografias de instituições culturais centenárias e a edição de obras já esgotadas sem interesse mercadológico, mas com valor histórico (Filó, 2013). O CFC atuou até 1975.

Os itens impressos foram novamente citados em norma legal a partir do seu valor artístico na Lei ${ }^{\circ} 5.471$, de 09 de julho de 1968, que dispõe sobre a exportação de livros antigos e conjuntos bibliográficos brasileiros. Destaca-se que para o efeito desta norma foram considerados como fontes de informação diversas além do livro antigo, os periódicos, as partituras e os acervos documentais. A lei estabeleceu um critério de antiguidade e uma temática para caracterizar as bibliotecas ou os conjuntos bibliográficos passíveis de proteção, ou seja, os acervos de obras brasileiras ou de obras sobre o Brasil, editadas entre os séculos XVI a XIX.

Uma nova norma específica sobre o tema foi sancionada em seguida, o Decreto $^{\circ}$ 65.347, de 13 de outubro de 1969, que regulamenta a lei anterior. As duas normas se distinguem quanto à menção aos acervos de natureza pública e privada detentores de livros raros e outros materiais bibliográficos de valor histórico. Contudo, em ambas prevaleceu o controle sob a circulação destes bens perante o risco iminente de perda através da exportação ilícita, do que propriamente o amplo reconhecimento dos livros raros e antigos como elementos da cultura nacional.

Ao longo da década de 1970, a proteção do patrimônio bibliográfico mudou de perspectiva. A atenção não estava mais centrada na identificação, na aquisição e no controle da circulação de obras raras, mas na formação e na manutenção de acervos de bibliotecas de valor histórico. Os compromissos lançados em eventos, promovidos por instituições federais sobre a proteção do patrimônio cultural recomendavam a criação dos órgãos estaduais e municipais dedicados à área, a promoção de cursos para suprir as carências de mão de obra especializada e a defesa dos patrimônios natural, arquivístico e bibliográfico, entre outros.

O Compromisso de Brasília firmado durante o I Encontro dos Governadores sobre a Defesa do Patrimônio Histórico e Artístico do Brasil, realizado pelo Conselho Federal de Cultura, entre 1 a 3 de abril de 1970, contou com a participação de secretários estaduais da área cultural, prefeitos de municípios interessados, presidentes e representantes de instituições culturais. $\mathrm{O}$ evento destacou a necessidade de aproveitamento de edifícios históricos tombados com a criação de arquivos, bibliotecas, casas de cultura e museus; e a importância do envolvimento dos órgãos federais, estaduais e municipais, além do poder legislativo e judiciário e das universidades, para melhor gerenciamento e controle do patrimônio cultural (Maia, 2010-2011: 78). Em relação ao patrimônio bibliográfico o Compromisso de Brasília (1970: 2-3) estabelecia que: 
Art. 10. Caberá as universidades o entrosamento com bibliotecas e arquivos públicos nacionais, estaduais e municipais, bem assim os arquivos eclesiásticos e de instituições de alta postura, no sentido de incentivar a pesquisa quanto à melhor elucidação do passado e à avaliação de inventários dos bens regionais cuja defesa se propugna. (...)

Art. 13. Recomenda-se a conservação do acervo bibliográfico, observadas as normas técnicas oferecidas pelos órgãos federais especializados na defesa, instrumentação e valorização desse patrimônio.

A progressiva ampliação do conceito de patrimônio cultural para além dos monumentos e das obras de arte, compreendendo o conjunto de bens culturais, efetivou-se por meio da Convenção relativa às medidas destinadas a proibir e impedir a exportação, a importação e a transferência de propriedade ilícita de bens culturais, realizada durante a Assembleia Geral da Unesco, realizada em Paris, entre 12 a 14 de novembro de 1970. A expressão bens culturais passou a significar "quaisquer bens que, por motivos religiosos ou profanos, tenham sido expressamente designados por cada Estado como de importância para a arqueologia, a pré-história, a história, a literatura, a arte ou a ciência" (UNESCO, 1970). O texto desta convenção estabeleceu onze categorias de bens culturais (móveis e imóveis), de grande importância para o patrimônio cultural de cada país que deviam ser protegidos, entre eles os bens culturais de natureza bibliográfica: manuscritos raros e incunábulos, livros, documentos e publicações antigos de interesse especial (histórico, artístico, científico, literário, etc.), isolados ou em coleções. O Brasil ratificou esta Convenção três anos depois, através do Decreto $\mathrm{n}^{\circ} 72.312$, de 31 de maio de 1973, que também não teve grande alcance legal.

A Convenção de 1970 serviu de base para as diretrizes do Compromisso de Salvador lançado no II Encontro de Governadores para Preservação do Patrimônio Histórico, Artístico, Arqueológico e Natural do Brasil, promovido pelo MEC e IPHAN, realizado em outubro de 1971, em Salvador (BA). O documento aprovado durante o evento recomendava que o Tribunal de Contas destinasse porcentagens do Fundo de Participação de Estados e Municípios aos museus, as bibliotecas e os arquivos, com acervos de importância comprovada. O texto final ainda determinava a edição de obras comemorativas por estas instituições culturais: "Art. 24. A publicação pelas administrações estaduais e municipais de livros e documentos referentes à história da independência brasileira, nas suas respectivas áreas, por ocasião do transcurso do sesquicentenário da independência" (Compromisso de Salvador, 1971).

A ênfase governamental no resgate histórico motivou a criação do Centro Nacional de Referência Cultural (CNRC) em 1975, com o objetivo de levantar fontes de informação sobre a cultura brasileira, inclusive obras bibliográficas. A 
proposta não era recolher bens culturais, mas criar um banco de dados sobre a cultura do País, mediante aplicação de técnicas das Ciências Sociais, Documentação e Informática. O CNRC foi idealizado como um centro de documentação para identificação e acesso aos produtos culturais brasileiros, a partir da compreensão da cultura sob o ponto de vista antropológico (Malhano, 2002).

$\mathrm{Na}$ fase inicial, o Centro era divido em quatro áreas: Ciências Humanas, Ciências Exatas, Documentação, Artes e Literatura. Depois se estruturou em quatro programas: Mapeamento do artesanato brasileiro; Levantamentos socioculturais; História da ciência e da tecnologia no Brasil; e Levantamentos de documentação sobre o Brasil. Este último colaborou para a defesa do patrimônio bibliográfico na divulgação de obras raras sobre o País existentes no exterior ou não acessíveis ao público até então como o Mapa etno-bistórico de Curt Nimuendaju e o livro $A$ expedição científica de G. I. Langsdorff ao Brasil (1821-1829). Apesar do caráter inovador, o CNRC foi incorporado à Fundação Pró-Memória, em 1979.

$\mathrm{Na}$ segunda metade da década de 1970, observa-se a estagnação de leis e de políticas dedicadas ao patrimônio bibliográfico. O Brasil não ratificou a Recomendação sobre o intercâmbio internacional de bens culturais (1976) e a Recomendação sobre a proteção dos bens culturais móveis (1978), propostas pela Unesco. Em âmbito regional, o País também não aderiu à Convenção sobre Defesa do Patrimônio Arqueológico, Histórico e Artísticos das Nações Americanas, mais conhecida como "Convenção de São Salvador", aprovada na reunião da Organização dos Estados Americanos (OEA), realizada no Chile, em 1976.

Os três textos tiveram especial importância para a Biblioteconomia de Livros Raros ao atribuírem não só ao museu, mas também às instituições culturais similares, como as bibliotecas e os arquivos, a tarefa de zelar pela guarda e gestão dos bens culturais móveis. Os reflexos dessa decisão colaboraram para a continuidade da reedição maciça de obras raras e das deficiências das bibliotecas brasileiras, no que tange a identificação e o tratamento técnico de suas coleções especiais.

Só a partir da década de 1980 é que os acervos de obras raras começaram a ser amplamente divulgados no País, a medida que as instituições de guarda obtiveram recursos técnicos, humanos e financeiros - em grande parte oriundos da iniciativa privada - para proceder ao inventário e a catalogação destes materiais. A Fundação Biblioteca Nacional (FBN) no Rio de Janeiro assumiu a tarefa de identificação de acervos de livros raros brasileiros por meio da atuação do Plano Nacional de Recuperação de Obras Raras (PLANOR, http://planorweb.bn.br/).

O PLANOR foi criado através da Portaria no 19, de 31 de outubro de 1983, com o objetivo de identificar, coletar, reunir e disseminar informações sobre acervos raros existentes no Brasil; prestar assessoria e orientar sobre 
procedimentos técnicos de identificação, organização, tratamento técnico e gestão desse patrimônio, conforme normas adotadas pela FBN; e desenvolver programas de formação e aperfeiçoamento de mão de obra especializada.

Com a abertura do País e a restauração da democracia, a Constituição Federal de 1988, ampliou o conjunto de bens pertencentes ao patrimônio cultural entre materiais e imateriais, mas suprimiu os bens de valor bibliográfico:

Art. 216. Constituem patrimônio cultural brasileiro os bens de natureza material e imaterial, tomados individualmente ou em conjunto, portadores de referência à identidade, à ação, à memória dos diferentes grupos formadores da sociedade brasileira, nos quais se incluem:

I - as formas de expressão;

II - os modos de criar, fazer e viver;

III - as criações científicas, artísticas e tecnológicas;

IV - as obras, objetos, documentos, edificações e demais espaços destinados às manifestações artístico-culturais;

$\mathrm{V}$ - os conjuntos urbanos e sítios de valor histórico, paisagístico, artístico, arqueológico, paleontológico, ecológico e científico. (Constituição, 1988)

Autores dedicados ao campo do Direito do Patrimônio Cultural consideram que a menção a várias categorias no texto constitucional é vaga e inconveniente, sendo usada apenas para exemplificar a diversidade de bens culturais, existentes no País, ao invés de falar em bens de relevante valor cultural, o que seria ainda mais generalista (Rabello, 2009; Paiva, 2010; Rodrigues, 2012).

\section{0 período: $1989-2015$}

O processo de reconhecimento do patrimônio bibliográfico prosseguiu por esforços da Fundação Biblioteca Nacional, para divulgação dos acervos de livros raros identificados até então, por intermédio das duas edições do guia Catálogos brasileiros de obras raras, publicados por bibliotecas e instituições brasileiras, em 1989 e 1997.

Neste intervalo, os bens culturais de natureza bibliográfica voltaram a ser citados em norma legal, ainda que de forma implícita, devido à necessidade de disseminação de bibliotecas públicas. O Decreto n ${ }^{\circ}$ 520, de 13 de maio de 1992, que instituiu o Sistema Nacional de Bibliotecas Públicas (SNBP), também definiu como um dos seus objetivos a circulação de bens culturais pelo acesso ao livro. $\mathrm{O}$ art. $4^{\circ}$ estabelecia a possibilidade de convênios e contratos de prestação de serviços entre o SNBP e a sociedade com vistas ao incremento da circulação de bens culturais, o que não resultou em práticas efetivas em prol do patrimônio bibliográfico.

Ainda que não se trate de mecanismos legais e públicos para a proteção dos bens culturais impressos, devem ser mencionadas as atividades de inventário 
e divulgação dos acervos de obras raras em bibliotecas eclesiásticas. A Igreja, reconhecida como a maior detentora de bens de valor artístico e histórico no Brasil, é também a percussora na elaboração de políticas e normas sobre a matéria (Menezes, 2006). Os instrumentos normativos para a proteção do patrimônio cultural sacro são anteriores a legislação brasileira de proteção do patrimônio histórico: o Decreto Consistorial de 1909; a Carta Pastoral Coletiva e a Constituição Eclesiástica do Brasil, ambas de 1915; o Código de Direito Canônico de 1917, que acentuava a necessidade de inventário e preservação dos bens de valor histórico e artístico, bem como a proibição de venda; e a Carta Pastoral do Episcopado Mineiro de 1926, que tratava do patrimônio artístico.

No entanto, os trabalhos de preservação das bibliotecas eclesiásticas no Brasil foram consolidados a partir das publicações da Pontificia Commissione per i Beni Culturali dela Chiesa como Le biblioteche ecclesiastiche nella missone dela chiesa (1994) e Necessidade e urgência da inventariação e catalogação do patrimônio cultural da Igreja (1999). As cartilhas ressaltavam o valor cultural das bibliotecas criadas e mantidas pela Igreja Católica ao redor do mundo, bem como a importância do levantamento de dados sobre as coleções como instrumento de proteção do patrimônio cultural sacro.

O Ministério Público do Estado de Minas Gerais publicou o Manual básico de segurança e conservação do patrimônio cultural sacro (2010), material informativo sobre os desafios e os mecanismos para a proteção do patrimônio eclesiástico semelhante às cartilhas editadas pelo Vaticano, mas que não cita as coleções bibliográficas. Assim, os acervos das bibliotecas católicas, principalmente aqueles detentores de livros raros estão sendo protegidos por iniciativas locais das paróquias, à medida que são inventariados, possibilitando a sua inserção em bases de dados especializadas, a exemplo do Catálogo do Patrimônio Bibliográfico Nacional (CPBN).

Inspirado no trabalho da Biblioteca Nacional da Espanha em mapear os acervos raros através do Catálogo Colectivo do Patrimonio Bibliográfico Espanhol (CCPB), a FBN, por meio do PLANOR, criou em 1995 o CPBN, com objetivo de reunir dados referenciais e registros bibliográficos de obras dos séculos XV ao XIX, de acervos raros de instituições públicas e privadas existentes no País, divulgados através de catálogo online. ${ }^{5}$

Neste mesmo período, o Decreto n ${ }^{\circ}$ 1.494, de 17 de maio de 1995, estabeleceu a sistemática do Programa Nacional de Apoio à Cultura (PRONAC) que conceituava o patrimônio cultural como: "art. 3. Conjunto de bens materiais e imateriais de interesse para a memória do Brasil e de suas correntes 
culturais formadoras, abrangendo o patrimônio arqueológico, arquitetônico, arquivístico, bibliográfico, científico, ecológico, etnográfico, histórico, museológico, paisagístico, paleontológico e urbanístico, dentre outros".

O PRONAC inaugurou uma nova fase em relação à gestão de acervos raros com as políticas de incentivo à cultura para o financiamento de projetos de reforma de instalações físicas, restauração e tratamento técnico. Contudo, o Decreto 1.494/95 revogado pelo Decreto n ${ }^{\circ}$ 5.761, de 27 de abril de 2006, não estabeleceu nenhuma medida expressiva de apoio ao patrimônio bibliográfico, apenas à literatura, o que não especifica se são ações de estímulo à leitura e à formação de bibliotecas ou a valorização de acervos de obras raras e antigas.

Observa-se que um dos entraves à elaboração de normas específicas de proteção ao patrimônio bibliográfico no Brasil é a ausência do conceito desta modalidade de patrimônio cultural, o que acabou por associar as coleções bibliográficas aos acervos arquivísticos, como reflexo da política de preservação do patrimônio documental adotada no País ao longo do século XX:

Se entre os bens tombados entre o fim dos anos de 1930 e os de 1990 pelo Serviço de Patrimônio não havia arquivos e documentos de arquivos (apesar de se contemplarem algumas coleções museológicas), existem autores que veem a proteção do acervo arquivístico implícita no acervo bibliográfico já que quando da criação da SPHAN acervos documentais reconhecidos como historicamente dignos de cuidados eram não raro, identificados como aqueles existentes nas seções de manuscritos das bibliotecas publicas e privada. (Parella, 2012: 44)

A indefinição conceitual persistiu nas ações para a identificação e a salvaguarda de acervos documentais de interesse mundial, como na Portaria do Ministério da Cultura n ${ }^{\circ} 259$, de 2 de setembro de 2004, que criou o Comitê Nacional do Brasil do Programa Memória do Mundo da UNESCO (MoWBrasil). ${ }^{6}$ A portaria não apresenta uma clara delimitação entre patrimônio documental, patrimônio arquivístico e patrimônio bibliográfico, conforme discriminado nos objetivos do Programa citados pelo art. $3^{\circ}$ :

I - Promover os objetivos do Programa Memória do Mundo da UNESCO, de acordo com suas diretrizes, que visam assegurar a preservação e o acesso ao patrimônio documental e bibliográfico de importância mundial. (...)

O Memory of the World Programme foi criado em 1992, com o objetivo de assegurar a preservação e o acesso a documentos e conjuntos documentais de importância mundial, além da conscientização por meio de seu registro na lista do patrimônio documental da humanidade. O programa congrega as instituições e os seus respectivos acervos de interesse em comitês regionais. O Brasil integra o Memory of the World Latin American and Caribean Regional Committee (MOWLAC). 
VI - Apoiar os órgãos competentes na formulação de políticas nacionais que permitam definir, registrar, salvaguardar e dar acesso ao patrimônio arquivístico e bibliográfico do Brasil.

VII - Propor mecanismos que favoreçam a Cooperação, a difusão e o intercâmbio da informação sobre a conservação do patrimônio documental e bibliográfico do País.

VIII - Promover junto aos órgãos públicos e entidades da Administração Pública do País e de Instituições Privadas, a conscientização para a salvaguarda do Patrimônio documental e bibliográfico do Brasil, considerando parte essencial de nosso patrimônio cultural. (Ministério da Cultura, 2004)

O emprego inadequado das expressões coleções documentais, fundos arquivisticos e coleções bibliográficas como sinônimos, bem como a noção de patrimônio arquivístico e o patrimônio bibliográfico como parte do patrimônio documental, persistiu na nova norma do MINC sobre o tema. A Portaria n 61 , de 31 de outubro de 2004, que aprovou o Regulamento do Comitê Nacional do Brasil do Programa Memória do Mundo da UNESCO, ${ }^{7}$ definiu o objetivo do Comitê: “(...) assegurar a preservação de documentos e conjuntos documentais de importância mundial, de natureza arquivística ou bibliográfica, por meio de seu registro na lista do patrimônio documental da humanidade, democratizar o acesso a esses documentos e conscientizar sobre a sua importância”.

Nota-se que a Portaria do MINC não conceitua o que vem a ser o patrimônio documental. De acordo com a UNESCO esta modalidade de patrimônio é definida como: “(...) as comprising items which are: moveable (but see below); made up of signs/codes, sounds and/or images; preservable (the carriers are non-living); reproducible and migratable; the product of a deliberate documenting process" (Edmondson, 2002: 8).

7 O MINC por meio da Portaria n ${ }^{\circ}$ 72, de 17 de agosto de 2015, designou a $5^{\text {a }}$ composição do Comitê MOWBrasil, mandato 2015-2017, com validade a partir de 3 de outubro de 2015, composto por dezoito membros, que representam as principais instituições dedicadas à salvaguarda do patrimônio documental no País, em sua maioria de autarquia federal. A Fundação Biblioteca Nacional continua a ser a única representante do Comitê dedicada prioritariamente à gestão e à salvaguarda de coleções bibliográficas. Os demais representantes são instituições arquivísticas, museais, eclesiásticas, órgãos de proteção do patrimônio cultural e especialistas de notório saber na área de preservação de acervos documentais. A FBN possui apenas uma coleção com registro internacional no Programa Memória do Mundo. Trata-se da Coleção do Imperador: Fotografia Brasileira e Estrangeira do Século XIX. Os manuscritos, a iconografia e a música impressa são os principais elementos que caracterizam as coleções da FBN indicadas para o registro nacional, que estão em processo de reconhecimento internacional: Carta de Abertura dos Portos Marítimos para o Comércio com as Nações Amigas de 1808; "Viagem Filosófica": expedição científica de Alexandre Rodrigues Ferreira nas capitanias do Grão-Pará, Rio Negro, Mato Grosso e Cuiabá - 1783-1792; Atlas e mapa do cartógrafo Miguel Antônio Ciera (1758); Manuscritos musicais de Carlos Gomes e Ernest Nazaretb; A Guerra da Tríplice Aliança: Representações Iconográficas e Cartográficas. 
Dessa forma, a abrangência dos acervos a serem contemplados pelo Programa Memória do Mundo no Brasil seguem as categorias propostas pela UNESCO:

- Textual items such as manuscripts, books, newspapers, posters, etc. The textual content may be recorded in ink, pencil, paint or other medium. The carrier may be of paper, plastic, papyrus, parchment, palm leaves, bark, textile fabric, stone or other medium.

- Similarly, non-textual items such as drawings, prints, maps, music.

- Audiovisual items such as films, discs, tapes and photographs - whether recorded in analogue or digital formats, and by mechanical, electronic or other means - comprise a physical carrier with an information bearing layer where the content resides.

- Virtual documents such as websites reside on servers: the carrier may be a hard disc or tape, the content is electronic data. (Edmondson, 2002: 8-9)

A definição mais detalhada do patrimônio bibliográfico referente às coleções de manuscritos, livros antigos e raros, está vinculada a prática do comércio de obras de arte, conforme expresso pela Instrução Normativa do IPHAN $\mathrm{n}^{\circ}$ 1, de 11 de junho de 2007, que dispõe sobre Cadastro Especial dos Negociantes de Antiguidades, de Obras de Arte de Qualquer Natureza, de Manuscritos e Livros Antigos ou Raros. A normativa estabelece no art. $3^{\circ}$ a obrigatoriedade de registro de pessoas que negociam bens culturais. Inclui no inciso $\mathrm{X}$ os livros raros e antigos consagrados na literatura especializada, ou que tenham valor literário, histórico ou cultural permanente:

a) a Coleção Brasiliana: livros sobre o Brasil - no todo ou em parte, impressos ou gravados desde o século XVI até o final do século XIX (1900 inclusive), e os livros de autores brasileiros impressos ou gravados no estrangeiro até 1808 ;

b) a Coleção Brasiliense: livros impressos no Brasil, de 1808 até nossos dias, que tenham valor bibliofílico: edições da tipografia régia, primeiras edições por unidades federativas, edições príncipes, primitivas ou originais e edições em vida - literárias, técnicas e científicas; edições fora de mercado, produzidas por subscrição; edições de artista;

c) Os incunábulos, pós-incunábulos e outras edições impressas e gravadas, célebres ou celebrizadas, de evidenciado interesse para o Brasil, impressas artesanalmente nos séculos XV a XVIII (1800 inclusive), em qualquer lugar; d) As publicações periódicas e seriadas, em fascículos avulsos ou coleções: títulos sobre o Brasil - no todo ou em parte, impressos ou gravados no estrangeiro até 1825; títulos impressos ou gravados no Brasil, de 1808 a 
1900, inclusive; folhas volantes - papéis de comunicação imediata, originalmente soltos e esporádicos, impressas ou gravadas no Brasil, no século XIX (1900 inclusive); os títulos manuscritos, configurados como jornalismo epistolar, produzidos ou não sob subscrição no Brasil, no século XIX (1900 inclusive); os títulos célebres ou celebrizados, de evidenciado interesse para o Brasil, impressos ou gravados artesanalmente, nos séculos XVI a XVIII (1800 inclusive), em qualquer lugar.

Verificou-se que a normativa do IPHAN se baseia no Brasil enquanto temática e em critérios de raridade relativos à antiguidade, ineditismo, produção e circulação de livros e periódicos. No entanto, a proposta foi mais abrangente ao incluir no inciso XI as marcas de propriedade em obras de interesse internacional:

Os exemplaares de livros ou fascículos de periódicos representativos, respectivamente, da memória bibliográfica e hemerográfica mundial, avulsos ou em volumens organizados ou factícios, que apresentem marcas de colecionismo ativo ou memorial, tais como: exlibris, super librios, ex-donos e carimbos secos ou molhados; marcas de leitura personaalizadas; marcas de exemplar de autor, com anotações autógrafas ou firmadas que evidenciam o amadurecimento e a redifinição do texto.

Dentre as ações mais recentes em prol da defesa dos bens culturais de natureza bibliográfica, deve-se citar o lançamento do Guia do Patrimônio Bibliográfico Nacional de Acervo Raro (2012), que relaciona os acervos de livros raros já identificados no país através do trabalho do CPBN e do PLANOR. Entretanto, a publicação não informa se estes acervos dispõem de algum mecanismo de proteção legal, a exemplo do tombamento.

Em 2014, uma série de eventos foram realizados por instituições públicas detentoras de acervos de livros raros, que abordaram a temática do $\mathrm{Pa}$ trimônio Bibliográfico e Documental. ${ }^{8}$ Todavia, ao final das discussões não foram elaborados documentos capazes de caracterizar estas modalidades de patrimônio cultural no País; propostas emendas para redação de normas legais específicas; ou apresentadas diretrizes para orientar os gestores de instituições mantenedoras de bens culturais móveis de natureza bibliográfica quanto as possibilidades de proteção jurídica deles.

8 Foram eles: I Jornada sobre Gestão e Desenvolvimento de Coleções Especiais - Universidade Estadual Paulista (Unesp); Jornada de estudos: Patrimônio bibliográfico e documental - Universidade Federal de Minas Gerais (UFMG); I Fórum Internacional sobre Livros Antigos, Raros e Especiais - Universidade Federal do Estado do Rio de Janeiro (UNIRIO); XI Encontro Nacional de Acervo Raro - Gestão de Acervos Raros e Especiais: realidades e desafios - PLA$\mathrm{NOR} / \mathrm{FBN}$. 
Em síntese, as leis e as políticas culturais relacionadas ao tema "patrimônio bibliográfico" no Brasil se restringiram à publicação de livros para distribuição gratuita em instituições públicas; à reedição de obras raras e preciosas em datas comemorativas; ao controle à circulação das brasilianas, editadas até o final do século XIX, devido ao seu valor histórico e artístico internacional; e ao registro da produção intelectual das obras editadas no Brasil, independente da temática, no século XX.

$\mathrm{Na}$ próxima seção, analisaremos os instrumentos de proteção legal do patrimônio cultural passíveis de aplicação ao patrimônio bibliográfico, para tentar reverter este cenário.

\section{INSTRUMENTOS DE PROTEÇÃO LEGAL PASSÍVEIS DE APLICAÇÃO AO PATRIMÔNIO BIBLIOGRÁFICO NO BRASIL}

A proteção do patrimônio cultural no Brasil é um dever do Estado, que consiste na adoção de um ato administrativo - tombamento provisório ou definitivo, lei específica, dentre outras formas de acautelamento, como inventário e decisão judicial - a partir de sua publicação. O art. 216 da Constituição de 1988 estabeleceu os seguintes instrumentos de proteção do patrimônio cultural: inventários, registros, vigilância, tombamento e desapropriação, e outras formas de acautelamento e preservação. Semelhante às modalidades de patrimônio cultural, o texto constitucional apenas cita as formas de proteção possíveis, sem estabelecer metodologias para sua aplicação.

Os tipos de instrumentos diferem de acordo com as peculiaridades dos bens culturais a serem protegidos, se são materiais ou imateriais, móveis ou imóveis. Para Fonseca (2009), os principais instrumentos de proteção do patrimônio cultural brasileiro são o tombamento para bens imóveis e os museus para a guarda dos acervos de bens móveis. Dessa forma, a proteção dos acervos bibliográficos e congêneres é indireta, perpassa a noção de paisagem cultural pela percepção coletiva do território da arte; sua vinculação a instituições museológicas e aos edifícios históricos; ou por meio de outras normas legais.

A seguir apresentamos uma breve explicação sobre os principais instrumentos de proteção legal aplicáveis aos bens culturais móveis:

a) Tombamento: o termo tombamento é exclusivo da língua portuguesa e tem origem na palavra tombo com significado de inventário autêntico de bens, em referência ao Arquivo da Torre do Tombo, onde se conservam os livros, papéis autênticos, registros ou originais da 
lei, escrituras públicas, contratos e tratados do reino português com as nações estrangeiras (Bluteau, 1721: v. 8: 196-197; Vieira, 1874: v. 5: 760). Equivale ao termo registration, em inglês, e classement, em francês, enquanto processo de identificação e proteção especial dos bens culturais. É o instrumento jurídico mais utilizado na defesa do patrimônio cultural brasileiro, regulado por norma específica, o Decreto-Lei $n^{\circ} 25 / 37$. Assemelha-se a classificação na Lei do Patrimônio Cultural e Histórico em Portugal, à declaración de interés cultural na Ley del Património Histórico Espanbol e à dichiarazione dell'interesse culturale no Codice dei Beni Culturali e del Paesaggio na Itália (Paiva, 2010). É realizado exclusivamente por órgãos de proteção do patrimônio cultural - o IPHAN, em nível federal e as instituições congêneres, em nível estadual e municipal - e estabelece sanções de uso, modificação e circulação dos bens culturais. A proteção do bem cultural em nível federal se efetiva com a inscrição do mesmo em um dos quatro Livros do Tombo do IPHAN: Arqueológico, Etnográfico e Paisagístico; Histórico; Belas Artes; Artes aplicadas. O processo de tombamento em nível estadual e municipal pode compreender o registro em livro de tombo, ou apenas a publicação de lei, decreto ou portaria para este fim.

b) Inventário: visa descrever minuciosamente um bem, levantar e identificar características e valores culturais relacioná-lo e incluí-lo no rol do patrimônio cultural. Embora qualquer pessoa ou instituição possa realizar inventários dos bens culturais, o seu reconhecimento e proteção é facultada à menção em uma lista formal elaborada por órgãos estatais de proteção do patrimônio. Este instrumento ainda é pouco usado, porque não possui norma específica e metodologia definida, para sua execução, dada a grande variedade de bens culturais existentes. É aplicável para bens que não possuem valor notável ou excepcional, aqueles que não estejam ameaçados, que não corram perigo de destruição, e nos casos em que o Poder Público necessita atuar em caráter de urgência para a proteção de um bem. O inventário configura-se também como o início do processo de tombamento.

c) Vigilância: é o exercício do poder de polícia administrativa do Estado de caráter publicista para o bem-estar social, tendo em vista a defesa dos direitos coletivos. É realizado por intermédio dos trabalhos de fiscalização e seus desdobramentos. Os fiscais são o Ministério Público 
(Federal e Estadual), ${ }^{9}$ o IPHAN, os órgãos estaduais de preservação e os órgãos municipais de cultura. O Ministério Público atua com a edição de recomendações, cartilhas e material informativo para consolidação de textos legais e mais publicidade e divulgação dos mesmos. O IPHAN e demais órgãos de proteção através de portarias regulamenta diversos artigos constantes nas normas federais de proteção em vigor, dando melhor publicidade aos critérios estabelecidos.

Cabem aqui alguns esclarecimentos sobre a possível aplicação destes instrumentos de proteção em acervos bibliográficos, a começar pelo tombamento, que é o instrumento mais legislado e mais utilizado na proteção dos bens culturais, porém não é adotado de forma clara para a defesa do patrimônio bibliográfico.

Em 2013, o site do IPHAN (http://portal.iphan.gov.br) revelou que os bens culturais materiais sob proteção em nível federal incluíam 834 mil livros e documentos bibliográficos tombados, mas sem nenhuma menção às características desse material (se são obras raras ou contemporâneas), à identificação de suas coleções de origem e às bibliotecas de custódia. $\mathrm{Na}$ Lista dos bens culturais inscritos nos Livros de Tombo (1938-2012), também divulgados na homepage do IPHAN, os acervos tombados são tratados de modo generalista, sem especificar se trata de itens bibliográficos. Na relação de bens em processo de tombamento não havia nenhuma biblioteca inscrita (Ministério da Cultura, Instituto do Patrimônio Histórico e Artístico Nacional, 2013). O tombamento de bibliotecas quando ocorre, abrange apenas o edifício e não o seu acervo, mesmo que possua obras raras (Murguia e Yassuda, 2007). Este é o caso da Biblioteca Nacional, que tem o imóvel que a abriga tombado, pelo fato de integrar o conjunto arquitetônico do centro histórico da cidade do Rio de Janeiro. A importância cultural do seu acervo não foi considerada, por isso suas coleções não dispõe de nenhum instrumento de proteção legal.

Os dados mais recentes sobre os bens culturais sob proteção do IPHAN foram atualizados em 2015. A Lista dos bens tombados e Processos em andamento (1938-2015), relativa ao conjunto de bens integrantes do patrimônio material, indica que não houve novos pedidos de tombamento de bibliotecas e de coleções bibliográficas ${ }^{10}$ e que elas permanecem associadas à proteção dos edifícios históricos e dos conjuntos de bens culturais móveis neles

9 É um órgão do Estado de atuação administrativa, responsável pela defesa da ordem jurídica e dos interesses da sociedade, através da fiel observância da Constituição e das leis.

10 A lista foi divulgada pelo IPHAN em maio de 2015, um mês antes da abertura do processo de tombamento do edifício e do acervo de livros raros da Biblioteca Mário de Andrade, em São Paulo (SP). O imóvel, construído em 1936 e tombado em nível municipal em 1992, abriga a segunda maior coleção pública de obras raras do País. O pedido de tombamento da biblioteca marca as comemorações do septuagésimo aniversário de morte de seu patrono. 
armazenados, a exemplo dos acervos sacros e científicos (Ministério da Cultura, Instituto do Patrimônio Histórico e Artístico Nacional, 2015).

No caso do inventário, apesar de não existir uma metodologia única para a proteção de bens culturais, as técnicas de inventariação realizadas em bibliotecas (topográfico, analítico, histórico) não se afiguram como ações de acautelamento dos bens de natureza bibliográfica como patrimônio cultural. As informações recolhidas pelas bibliotecas sobre os seus respectivos acervos constituem o "levantamento cultural preliminar", um "pré-inventário" sem alcance jurídico. Estes podem vir a apoiar o inventário realizado por um órgão de proteção do patrimônio cultural, única entidade com legitimidade para atestar o valor cultural do acervo em questão.

Vale mencionar os aspectos relativos ao registro enquanto meio de acautelamento previsto na Constituição de 1988, que passou a ser regulado por norma exclusiva com a promulgação do Decreto $\mathrm{n}^{\circ} 3.551$, de 4 de agosto de 2000, que instituiu este instrumento para a proteção dos bens culturais de natureza imaterial. Semelhante ao tombamento, os bens intangíveis são inscritos pelo IPHAN em um dos quatro Livros de Registro do Patrimônio Cultural Imaterial (Saberes, Celebrações, Formas de Expressão e Lugares). Embora o Livro de Registro das Formas de Expressão inclua as manifestações literárias, ele não se refere especificamente ao conteúdo informativo e a transmissão do conhecimento pelo livro e demais impressos enquanto objeto de divulgação de textos, prosas e rimas, mas aos modos de fazer gêneros de literatura popular, que não necessariamente dependem da indústria editorial, a exemplo do Cordel. ${ }^{11}$

$\mathrm{Na}$ ausência de inventários de bens culturais móveis, os registros de coleções públicas custodiadas em arquivos, bibliotecas e museus apresentam-se como alternativas para a identificação e a divulgação dos itens salvaguardados por estas instituições. Porém, essa modalidade de registro também não possui alcance jurídico, a menos que seja reconhecida e validada por um órgão de proteção do patrimônio.

Dentre as demais formas de acautelamento mais associadas à proteção do patrimônio bibliográfico, podemos citar:

a) Depósito legal: visa reunir a produção intelectual do país a partir das datas de promulgação dos respectivos decretos que o regulamentam. O entendimento desta prática como instrumento de proteção dos bens culturais de natureza bibliográfica decorre da existência de

11 Literatura de Cordel é um gênero literário popular de origem portuguesa, escrito na forma rimada, baseado em relatos orais e impresso no formato de folhetos. O termo cordel tem origem na maneira como os folhetos eram expostos para venda, pendurados em cordas, cordéis ou barbantes, na região Nordeste do Brasil. 
norma específica sobre a matéria e da missão institucional da Biblioteca Nacional do Brasil - o registro e a guarda da produção intelectual nacional; o controle, a elaboração e a divulgação da Bibliografia Brasileira corrente; a defesa e a preservação da língua e da cultura nacionais. Entretanto, por questões gerenciais e físicas, a BN centralizou as atividades do depósito legal em relação aos impressos recentes, e dividiu com outras tipologias de bibliotecas a responsabilidade pela identificação, guarda e acesso aos livros raros e antigos. Portanto, o depósito legal afigura-se como uma obrigação jurídica e não como um instrumento de inventário cultural, porque não possui caráter seletivo, capaz de identificar quais obras raras e contemporâneas tem valor bibliográfico para a cultura brasileira. Isso ocorre porque, o depósito legal não possui caráter retrospectivo para à identificação e o recolhimento de livros raros e antigos sobre o Brasil, a exemplo dos materiais editados por brasileiros no exterior, entre o período colonial até o I Reinado. A exigência do depósito legal incide apenas sobre as obras editadas no território brasileiro, após o surgimento da indústria editorial local, no século XIX.

b) Ação civil pública: regulada pela Lei n ${ }^{\circ}$ 7.347, de 24 de julho de 1985, mais conhecida como Lei de Ação Civil Pública ou LACP, cujo objetivo é proteger os bens de interesses difusos ou coletivo ${ }^{12}$, que incluem o acesso ao patrimônio cultural preservado. É um mecanismo jurídico que apura responsabilidades sobre os danos causados ao meio-ambiente, ao consumidor, aos bens culturais e a qualquer outro interesse social. Em relação ao patrimônio cultural visa impedir a agressão ao bem cultural ou viabilizar sua recomposição. Pode ser proposta pelo Ministério Público, a União, os Estados e os Municípios, suas autarquias e fundações, as empresas públicas, as sociedades de economia mista e as associações.

c) Inquérito civil público: é um procedimento investigatório criado pela LACP, conduzido pelo Ministério Público, que visa basicamente investigar danos ao patrimônio público e aos interesses individuais homogêneos, coletivos e difusos, como os referentes ao meio ambiente, ao consumidor, ao patrimônio cultural e etc. O MP instaura o processo mediante denúncia ou demanda social. Em seguida requisita do organismo, público ou privado envolvido, as certidões,

12 O conceito de direito difuso ou coletivo tem origem na Lei n ${ }^{\circ} 808$, de 11 de setembro de 1990, mais conhecida como "Código de Defesa do Consumidor". Abrange os direitos transindividuais, aqueles cujos titulares são sujeitos indeterminados ligados por uma circunstância (grupos, categorias ou classes) e que visam a defesa de um bem ou direito coletivo. 
as informações, os exames ou perícias para averiguar possíveis danos ao patrimônio. O Ministério Público propõe as medidas que visem reverter o quadro da situação de risco. $\mathrm{O}$ processo termina com seu arquivamento, quando o organismo investigado atende a todas as recomendações do MP; caso contrário é proposta a ação civil pública.

Nos últimos anos, o MP tem sido um agente de destaque na proteção do patrimônio cultural, em especial no Estado de Minas Gerais. Entretanto, a ação e o inquérito civil apuram os danos ao patrimônio cultural, isto é, as situações de risco, perda, prejuízo ou descaracterização do bem cultural. Ambos se configuram como mecanismos de defesa e não de uma vontade espontânea de proteção do bem, apesar que em muitos casos, é após a instauração de um dos dois procedimentos pelo Ministério Público que um bem tem sua importância cultural reconhecida pela sociedade.

Em relação aos crimes cometidos contra o patrimônio cultural, estes são tipificados pela Lei n ${ }^{\circ}$ 9.605, de 12 de fevereiro de 1998, mais conhecida como Lei de Crimes Ambientais. A norma abrange também o patrimônio cultural porque segundo o ordenamento jurídico brasileiro os bens culturais fazem parte da paisagem, do ambiente em que o homem habita e se manifesta, o qual faz parte da natureza. $\mathrm{O}$ art. 62 estabelece que comete crime contra o patrimônio aquele que destruir, inutilizar ou deteriorar arquivo, registro, biblioteca, pinacoteca, instalação científica ou similar protegido por lei, ato administrativo ou decisão judicial. Para efeito desta norma, por biblioteca entende-se a "coleção de livros dispostos ordenadamente para estudo e consulta”. De acordo com Rodrigues (2012: 154):

(...) as instituições mencionadas no inciso II quando criadas pelo Poder Público, seja por lei ou outro ato administrativo, já deverão ser consideradas protegidas para fins penais, pelo simples fato de existirem. Pois se o Poder Público decidiu criar um arquivo, museu, biblioteca ou similar, presume-se que já reconheceu o valor cultural de um determinado acervo que se pretende ver preservado. Outro entendimento colocaria em sério risco a esmagadora maioria dos bens que se pretende proteger, tornando inócuo o tipo criminal. Basta verificar que entre os numerosos museus, arquivos e bibliotecas existentes no Brasil, muito poucos têm seus acervos tombados.

No entanto, nem sempre isso acontece. As críticas à Lei 9.605/98 para proteção de acervos de bens móveis incluem a ausência de tipos penais sobre a evasão de bens culturais móveis para o exterior. $\mathrm{O}$ crime de contrabando, por exemplo, é previsto no art. 334 do Código Penal, e só é caracterizado se for aplicada norma específica que proíbe ou restringe a remessa do bem cul- 
tural para o estrangeiro. No caso de contrabando de bens culturais de natureza bibliográfica as Leis 4.845/65 e 5.471/68, não garantem proteção efetiva, mesmo se aplicadas com outras normas legais por que:

(...) já bastante antigas, pecam pela utilização do critério temporal para definir o valor cultural, critério este não mais usado pela Constituição Federal. Assim, por esses diplomas legais, as obras de arte produzidas a partir de $16.11 .1889 \mathrm{e}$ os acervos bibliográficos do século XX e XXI ficam virtualmente desprotegidos. Isto levou à perda praticamente definitiva de uma obra de arte importante como o Abaporu, óleo de Tarsila do Amaral, que foi transferido para a Argentina. E permite a livre exportação de obras como a primeira edição de Os Sertões de Euclides da Cunha (1902), cujos exemplares receberam várias correções manuscritas a nanquim feitas pelo próprio autor. (Rodrigues, 2012: 168)

A Lei de Crimes Ambientais também não trata do comércio clandestino de bens culturais. Estes casos são previstos no art. 48 da Lei de Contravenções Penais que estabelece a pena de seis meses a quem exercer, sem observância das prescrições legais, comércio de antiguidades, de obras de arte, ou de manuscritos raros.

A atuação contra os delitos desta ordem é tarefa da Polícia Federal (PF) por intermédio da Delegacia de Repressão a Crimes Contra o Meio-Ambiente e Patrimônio Histórico (DELEMAPH), que possui uma unidade em todas as capitais e no distrito federal. Estas delegacias atuam com base na Lei 9.605/98, o que torna sua abrangência um desafio para o combate ao tráfico ilícito de bens culturais, porque são responsáveis também pelo combate aos crimes contra o meio-ambiente, o que demanda esforços ainda maiores de suas equipes. Observa-se que as investigações sobre roubos e comércio ilegal de itens bibliográficos, quando noticiadas, ganham repercussão na mídia, mas pouco contribui para conscientizar a sociedade da importância cultural dos acervos de livros raros e antigos; ou para promover ações integradas entre a PF e as bibliotecas na prevenção destes crimes.

Portanto, a adoção dos instrumentos de proteção jurídica do patrimônio cultural no Brasil é essencialmente coercitiva, ou seja, aplica-se mediante alguma ameaça ou mesmo ao dano já efetuado ao bem cultural. Embora as iniciativas de salvaguarda possam ser apresentadas aos órgãos competentes a qualquer momento, por qualquer cidadão. Segundo José Rodrigues, as solicitações de proteção legal de bens culturais quase sempre partem de cidadãos esclarecidos, grupos comunitários e estudiosos. Pouco antes do fechamento deste artigo, o IPHAN lançou a Carta aberta ao cidadão (2015), que apresenta informações básicas sobre os instrumentos de acautelamento citados acima e o processo de solicitação dos mesmos pela sociedade em geral, o que poderá contribuir para reverter este cenário. 


\section{Conclusões}

A trajetória de leis, políticas e instrumentos de proteção do patrimônio bibliográfico no Brasil foi marcada pela imprecisão de objetivos e a falta de continuidade. Observou-se que a legislação sobre o patrimônio cultural é antiga e necessita de ser aprimorada, de modo a contemplar toda a diversidade de bens culturais existentes no País. No caso específico dos bens culturais de natureza bibliográfica, as normativas são restritivas, porque tratam basicamente do depósito legal e do controle da circulação de livros raros. As políticas culturais se caracterizam pela impermanência, devido a extinção ou a supressão de órgãos estatais. Os instrumentos de defesa do patrimônio cultural previstos na Constituição, não contemplam adequadamente os bens culturais salvaguardados em bibliotecas.

A ausência de um conceito de patrimônio bibliográfico dificulta a criação de normas, políticas e instrumentos de acautelamento específicos para a defesa de acervos de livros raros e antigos. Vale lembrar que muitos acervos bibliográficos ainda estão sendo organizados e divulgados. Dessa forma, ainda não foi possível indicar com clareza quais são os títulos, os autores e as ediçõos mais emblemáticos para a formação da memória impressa desta nação.

Assim, a noção técnica e jurídica do que vem a ser o patrimônio bibliográfico no Brasil foi sendo construída pelo Estado, a partir da adesão a recomendações e projetos internacionais relacionados à raridade bibliográfica, a fim de evitar a evasão de livros raros e antigos pelo mercado clandestino de obras de arte. Todavia, os bens culturais de natureza bibliográfica não foram amplamente reconhecidos pelo Estado como bens de interesse público.

Verificou-se que não existiram debates e estudos aprofundados que realmente contemplassem o processo de desenvolvimento da imprensa, da leitura e das bibliotecas em diferentes regiões do País, como partes integrantes da cultura nacional. As normas disponíveis sobre a matéria surgiram mais por influência de intelectuais, de profissionais dedicados à comercialização de livros raros e de organismos internacionais do que propriamente pela necessidade de valorização da memória gráfica brasileira, por parte de bibliotecários e da sociedade em geral.

Portanto, é de suma importância o estudo da temática de proteção dos bens culturais móveis por parte de bibliotecários e gestores de acervos de livros raros, como uma ação contínua de salvaguarda destes itens em instituições culturais, e não apenas como uma medida paliativa ou urgente em situações limites que colocam em risco sua permanência e integridade física, como roubos, sinistros, catástrofes naturais ou mesmo decisões administrativas improcedentes. 


\section{REFERÊNCIAS}

Andrade, Mário de. 1993. A enciclopédia brasileira (Memória brasileira). São Paulo: Loyola, Ed. USP.

Askerud, Pernille y Etienne Clement, ed. 1999. La prevención del tráfico ilícito de bienes culturales: Un manual de la UNESCO para la implementación de la Convención de 1970. UNESCO, IPHAN.

Assembléa Geral Legislativa. Decreto n ${ }^{\circ} 433$, de 3 de julho de 1847. Obriga os impressores a remetter na Côrte á Bibliotheca Publica Nacional, e nas Provincias á Bibliotheca da Capital, hum exemplar de todos os impressos que sahirem das respectivas Typographias. Colecção de Leis do Império do Brazil I (1847). Acesso em 12 de fevereiro de 2015. http://www2.camara.leg.br/legin/fed/decret/1824-1899/ decreto-433-3-julho-1847-560144-publicacaooriginal-82761-pl.html

Baez, Fernando. 2006. História universal da destruição dos livros: das tábuas sumérias à guerra do Iraque. Rio de Janeiro: Ediouro.

Biblioteca Nacional (Brasil). 1989. Catálogos brasileiros de obras raras, publicados por bibliotecas e instituições brasileiras. Coleção Rodolfo Garcia. Rio de Janeiro: BN.

Bluteau, Raphael. 1708-1728. Vocabulario portuguez e latino. 10 vol. Lisboa: Na Officina de Pascoal da Sylva.

Calabre, Lia. 2009. Políticas culturais no Brasil dos anos 1930 ao século XXI. Coleção FGV de bolso. Série Sociedade e cultura. Rio de Janeiro: Ed. FGV.

Câmara dos Deputados. 2013. Legislação sobre patrimônio cultural. 2. ed. Série Legislação. Brasília: Ed. Câmara. Acesso em 10 de novembro de 2014. http://bd.camara.gov.br/bd/handle/bdcamara/4844\#

Campello, Bernadete. 2006. Introdução ao controle bibliográfico. 2. ed. Brasília: Briquet de Lemos.

Castriota, Leonardo Barci. 2009. "Patrimônio cultural: Valores e sociedade civil", em Mestres e conselheiros: Manual de atuação dos agentes do patrimônio cultural, Marcos Paulo de Souza Miranda, Guilherme Maciel Araújo e Jorge Abdo Askar (orgs.), 40-47. Belo Horizonte: IEDS.

Choay, Françoise. 2006. Alegoria do patrimônio. 4. ed. São Paulo: Estação Liberdade, UNESP.

Compromisso de Brasília. 1970. Acesso em 10 de janeiro de 2015. http://portal.iphan. gov.br/uploads/ckfinder/arquivos/Compromisso\%20de\%20Brasilia\%201970.pdf

Compromisso de Salvador. 1971. Acesso em 10 de janeiro de 2015. portal.iphan.gov. br/uploads/ckfinder/arquivos/Compromisso\%20de\%20salvador\%201971.pdf

Constituição dos Estados Unidos do Brasil (1937). Diário Oficial da União, 10 de novembro de 1937. Acesso em 1 de maio de 2015. http://www.planalto.gov.br/ccivil_03/constituicao/constituicao37.htm

Constituição da República Federal do Brasil (1988). Brasília: Senado Federal.

Cunha, Antônio Geraldo da. 2010. Dicionário etimológico da língua portuguesa. 4. ed. rev. e atual. Rio de Janeiro: Lexikon.

Decreto $n^{\circ} 1.494$, de 17 de maio de 1995. Regulamenta a Lei no 8.313, de 23 de dezembro de 1991, estabelece a sistemática de execução do Programa Nacional de Apoio à Cultura PRONAC, e dá outras providências. Diário Oficial da União, 18 maio, 1995. Acesso em 1 de maio de 2014. http://legis.senado.leg.br/legislacao/ ListaTextoIntegral.action? $\mathrm{id}=119275$ \& norma $=141334$ 
Decreto $\mathrm{n}^{\circ} 1.825$, de 20 de dezembro de 1907. Dispõe sobre a remessa de obras impressas à Biblioteca Nacional. Coleção de Leis da República dos Estados Unidos do Brasil 1 (1907). Acesso em 1 de maio de 2015. http://presrepublica.jusbrasil.com. br/legislacao/103708/decreto-1825-07

Decreto n ${ }^{\circ} 21.451$, de 30 de maio de 1932. Autoriza a aquisição direta, por parte do Ministério da Educação e Saúde Pública, aos editores ou a particulares, no país ou no estrangeiro, das publicações técnicas, científicas e outras, ou de edições de obras raras já esgotadas e dá outras providências. Coleção de Leis da República dos Estados Unidos do Brasil 2 (1932). Acesso em 30 de agosto de 2014. http://legis.senado.gov.br

Decreto n$^{\circ} 22.633$, de 12 de abril de 1933. Torna extensivo ao Ministério da Agricultura o decreto número 21.451, de 30 de maio de 1932, que autoriza a aquisição direta, por parte do Ministério da Educação e Saúde Pública, aos editores ou a particulares, no país ou no estrangeiro, de publicações técnicas, científicas e outras, ou de edições de obras raras, já esgotadas, e dá outras providencias. Coleção de Leis da República dos Estados Unidos do Brasil 2 (1933). Acesso em 30 de agosto de 2014. http://legis.senado.gov.br

Decreto $n^{\circ} 5.761$, de 27 de abril de 2006. Regulamenta a Lei no 8.313, de 23 de dezembro de 1991, estabelece sistemática de execução do Programa Nacional de Apoio à Cultura - PRONAC e dá outras providências. Diário Oficial da União, 28 abril, 2006. Acesso em 1 de maio de 2014. http://legis.senado.leg.br

Decreto $\mathrm{n}^{\circ} 520$, de 13 de maio de 1992. Institui o Sistema Nacional de Bibliotecas Públicas e dá outras providências. Diário Oficial da União, Seção 1, 14 maio, 1992. Acesso em 1 de maio de 2014. http://www.planalto.gov.br/ccivil_03/decreto/1990-1994/D0520.htm

Decreto n 65.347, de 13 de outubro de 1969. Regulamenta a Lei n. 5.471, de 9 de julho de 1968. Diário Oficial da União, Seção 1, 14 outubro, 1969. Acesso em 1 de maio de 2014. http://www.unesco.org/culture/natlaws/media/pdf/bresil/brazil_decreto_65347_13_10_1969_por_orof.pdf

Decreto-Lei $n^{\circ} 25$, de 30 de novembro de 1937. Organiza a proteção do patrimônio histórico e artístico nacional. Coleção de Leis do Brasil 3 (1937). Acesso em 1 de maio de 2014. http://www.planalto.gov.br/ccivil_03/decreto- lei/del0025.htm

Decreto-Lei n ${ }^{\circ}$ 526, de 1 de julho de 1938. Institue o Conselho Nacional de Cultura. Coleção de Leis do Brasil3 (1938). Acesso em 1 de maio de 2015. http://legis.senado.leg.br

Decreto-Lei no 93, de 21 de dezembro de 1937. Crea o Instituto Nacional do Livro. Coleção de Leis do Brasil 3 (1937). Acesso em 1 de maio de 2014. http://legis.senado.gov.br

Edmondson, Ray, ed. 2002. Memory of the World: General Guidelines. Revised edition. Paris: UNESCO. Acesso em 21 de setembro de 2014. http://unesdoc.unesco. org/images/0012/001256/125637e.pdf

Facciolati, Jacobo, Egidio Forcellini e Giuseppe Furlanetto. 1871. Lexicon totius latinitatis. Patavii: Typis Seminarii.

Faria, Maria Isabel e Maria da Graça Pericão. 2008. Dicionário do livro: Da escrita ao livro eletrônico. São Paulo: Ed. USP.

Ferreira, Aurélio Buarque de Holanda. 2009. Novo dicionário Aurélio da Língua Portuguesa. 4. ed. Curitiba: Positivo. 
Filó, Maurício da Cunha Savino. 2013. "Patrimônio cultural: Alcances e reflexos no Brasil”, em Patrimônio cultural, direito e cidadania, Daniel Ribeiro Preve, Alfredo Engelmann Filho e Juliano Bitencourt Campos (orgs.), 31-41. Erechin: Habilis.

Fonseca, Edson Nery da. 1972. "Bibliografia brasileira corrente: Evolução e estado atual do problema”. Ciência da Informação 1: 9-14.

Fonseca, Maria Cecília Londres. 2009. O patrimônio em processo: Trajetória política federal de preservação no Brasil. 3. ed. Rio de Janeiro: Editora UFRJ.

Guia do Patrimônio Bibliográfico Nacional de Acervo Raro. 2012. Rio de Janeiro: Fundação Biblioteca Nacional.

Lei n ${ }^{\circ} 10.994$, de 14 de dezembro de 2004. Dispõe sobre o depósito legal de publicações, na Biblioteca Nacional e dá outras providências. Diário Oficial da União, 15 dezembro, 2004. Acesso em 1 de maio de 2014. http://www.planalto.gov.br/ ccivil_03/_Ato2004-2006/2004/Lei/L10994.htm

Lei n ${ }^{\circ} 107$, de 8 de setembro de 2001. Estabelece as bases da política e do regime de proteção e valorização do património cultural. Diário da República, Série 1, n. 209, 8 setembro, 2001. Portugal. Acesso em 26 de abril de 2014. http://dre.pt/pdf1s/2001/09/209A00/58085829.pdf

Lei $n^{\circ} 4.845$, de 19 de novembro de 1965. Proíbe a saída, para o exterior, de obras de artes e ofícios, produzidos no país até o fim do período monárquico. Diário Oficial da União, 22 novembro, 1965. Acesso em 1 de maio de 2015. http://legis.senado.leg.br

Lei $n^{\circ} 5.471$, de 9 de julho de 1968. Dispõe sobre a exportação de livros antigos e conjuntos bibliográficos brasileiros. Diário Oficial da União, 10 julho, 1968. Acesso em 1 de maio de 2014. http://www.planalto.gov.br/ccivil_03/leis/L5471.htm

Lei $n^{\circ} 7.347$, de 24 de julho de 1985. Disciplina a ação civil pública de responsabilidade por danos causados ao meio ambiente, ao consumidor, a bens e direitos de valor artístico, estético, histórico e paisagístico, e dá outras providências. Diário Oficial da União, 25 julho, 1985. Acesso em 1 de maio de 2015. http://www2.camara.leg.br/legin/fed/lei/1980-1987/lei-7347-24-julho-1985-356939-normaatualizada-pl.pdf

Lei n ${ }^{\circ} 9.605$, de 12 de fevereiro de 1998. Dispõe sobre as sanções penais e administrativas derivadas de condutas e atividades lesivas ao meio ambiente, e dá outras providências. Diário Oficial da União, 13 fevereiro, 1998. Acesso em 1 de maio de 2015. http://www2.camara.leg.br/legin/fed/lei/1998/lei-9605-12-fevereiro-1998-365397-normaatualizada-pl.pdf

Ley n ${ }^{\circ}$ 16, de 25 de junio de 1985. Ley del Patrimonio Histórico Español, Boletín Oficial del Estado, 155, 29 junio, 1985. España. Acesso em 15 de abril de 2014. http:// noticias.juridicas.com/base_datos/Admin/116-1985

Maia, Tatyana de Amaral. 2010-2011. "O patrimônio cultural brasileiro em debate: A ação do Conselho Federal de Cultura (1967-1975)”. Revista CPC 11: 60-86.

Malhano, Clara Emília Sanches Monteiro de Barros. 2002. Da materialização à legitimação do passado: A monumentalidade como metáfora do Estado, 1920-1945. Rio de Janeiro: FAPERJ/Lucerna.

Menezes, Ivo Porto. 2006. Bens culturais da Igreja. São Paulo: Edições Loyola.

Michaelis, H. e Walter Weiszflog. 1998. Michaelis: Moderno dicionário da língua portuguesa. São Paulo: Melhoramentos. 
Ministério da Cultura. 2004. Portaria n ${ }^{\circ} 259$, de 2 de setembro de 2004. Cria o Comitê Nacional do Brasil do Programa Memória do Mundo da UNESCO. Diário Ofcial da União, 6 setembro. Acesso em 21 de setembro de 2014. http://www.portalan.arquivonacional.gov.br/Media/Portaria\%20259\%20de\%202004.pdf

Ministério da Cultura. Fundação Biblioteca Nacional. 1997. Catálogos brasileiros de obras raras, publicados por bibliotecas e instituições brasileiras. 2. ed. Coleção Rodolfo Garcia. Rio de Janeiro: Fundação Biblioteca Nacional.

Ministério da Cultura. Instituto do Patrimônio Histórico e Artístico Nacional. 2015. Carta ao cidadão. Brasília: IPHAN. Acesso em 20 de junho de 2015. http://portal. iphan.gov.br/uploads/ckfinder/arquivos/CartaCidadaoweb.pdf

Ministério da Cultura. Instituto do Patrimônio Histórico e Artístico Nacional. Instrução Normativa n ${ }^{\circ}$ 01, de 11 de junho de 2007. Dispõe sobre o Cadastro Especial dos Negociantes de Antiguidades, de Obras de Arte de Qualquer Natureza, de Manuscritos e Livros Antigos ou Raros, e dá outras providências. Acesso em 1 de maio de 2014. http://portal.iphan.gov.br/files/Instrucao_Normativa_Negociantes_012007.pdf

Ministério da Cultura. Instituto do Patrimônio Histórico e Artístico Nacional. 2013. Lista dos bens culturais inscritos nos Livros de Tombo (1938-2012). Rio de Janeiro: IPHAN. Acesso em 1 de maio de 2015. http://portal.iphan.gov.br/portal/baixaFcdAnexo.do?id=3263

Ministério da Cultura. Instituto do Patrimônio Histórico e Artístico Nacional. 2015. Lista dos bens tombados e Processos em andamento (1938-2015). Rio de Janeiro: IPHAN. Acesso em 1 de junho de 2015. http://portal.iphan.gov.br/uploads/ckfinder/arquivos/Lista_Bens_Tombados_pelo_Iphan_\%202015.pdf

Ministério da Cultura. Portaria n ${ }^{\circ}$ 61, de 31 de outubro de 2004. Aprova o Regulamento do Comitê Nacional do Brasil do Programa Memória do Mundo da UNESCO. Diário Oficial da União, 5 novembro, 2004. Acesso em 21 de setembro de 2014. http://www. portalan.arquivonacional.gov.br/Media/Portaria\%2060\%20e\%2061.pdf

Ministério da Cultura. Portaria $\mathrm{n}^{\circ} 72$, de 17 de agosto de 2015. Designa os membros do Comitê Nacional do Brasil do Programa Memória do Mundo da UNESCO, para mandato de dois anos, a contar de 3 de outubro de 2015. Diário Oficial da União, Brasília, Seção 2, 19 agosto 2015. Acesso em 20 de agosto de 2015. http:// www.portalan.arquivonacional.gov.br

Ministério da Educação e Cultura. 1980. Proteção e revitalização do patrimônio cultural no Brasil: Uma trajetória. Publicações da Secretaria do Patrimônio Histórico e Artístico Nacional. Brasília: SPHAN, Pró-Memória.

Ministério Público. 2010. Manual básico de segurança e conservação do patrimônio cultural sacro. [Belo Horizonte]: MPMG, SCI. Acesso em 29 de abril de 2014. http:// www-antigo.mpmg.mp.br/portal/public/interno/index/id/2

Miranda, Marcos Paulo de Souza. 2006. Tutela do patrimônio cultural brasileiro: Doutrina, jurisprudência, legislação. Belo Horizonte: Del Rey.

Miranda, Marcos Paulo de Souza. 2012. "Evolução histórica da legislação protetiva do patrimônio cultural no Brasil", em Estudos de direito do patrimônio cultural, José Eduardo Ramos Rodrigues e Marcos Paulo de Souza Miranda, 195-215. Belo Horizonte: Fórum. 
Moraes, Rubens Borba de. 2010. Bibliografia Brasiliana: livros raros sobre o Brasil publicados desde 1504 até 1900 e obras de autores brasileiros do período colonial, 2 vol. São Paulo: Ed. USP, FAPESP.

Mouren, Raphaele. 2012. Manuel du patrimoine em bibliotheque. Collection Bibliotheques. Paris: Editions du Circle de la Librairie.

Murguia, Eduardo Ismael e Silvia Nathaly Yassuda. 2007. "Patrimônio histórico-cultural: Critérios de tombamento de bibliotecas pelo IPHAN". Perspectivas em Ciência da Informação 12 (3): 65-82.

OEA. 1976. Convenção sobre Defesa do Patrimônio Arqueológico, Histórico e Artísticos das Nações Americanas. Acesso em 27 de abril de 2014. http://www.oas.org/ juridico/english/sigs/c-16.html

Paiva, Carlos Magno de Souza. 2010. O regime jurídico do bem cultural edificado no Brasil. Ouro Preto: UFOP.

Paiva, Carlos Magno Souza e Marcos Paulo de Souza Miranda, orgs. 2011. Direito do patrimônio cultural: Compêndio da legislação brasileira. Ouro Preto: Ed. UFOP. Acesso em 2 de maio de 2014. https:/www.mpmg.mp.br/areas-de-atuacao/defesa-do-cidadao/patrimonio-historico-e-cultural/material-de-apoio

Palazzi, Fernando. 1946. Novíssimo dizionario dela lingua italiana: Etimológico, fraseológico, grammaticale, ideológico, nomeclatore e dei sinonimi. 7. ristampa. Milano: Casa Editriche Ceschina.

Parella, Ivana. 2012. Patrimônio documental e escrita de uma história da pátria regional: Arquivo Público Mineiro, 1835-1937. Coleção Olhares. São Paulo: Annablume, Belo Horizonte: PPGH-UFMG.

Pedraza Gracia, Manuel José. 2010. "La responsabilidade social y jurídica ante el patrimônio bibliográfico”. Pecia Complutense 7 (13): 41-52. Acesso em 26 de março de 2014. http://biblioteca.ucm.es/pecial/doc15144.pdf

Pinheiro, Ana Virgínia. 2009. Livro raro: Formação e gestão de coleções bibliográficas especiais. Apostila.

Pontifícia Comissão para os Bens Culturais da Igreja. 1999. Necessidade e urgência da inventariação e catalogação do patrimônio cultural da Igreja. Cidade do Vaticano, 8 de dezembro.

Pontificia Commissione per i Beni Culturali dela Chiesa. 1994. Le biblioteche ecclesiastiche nella missone dela chiesa. Roma, 19 marzo. Acesso em 28 de março de 2014. http://www.vatican.va/roman_curia/pontifical_commissions/pcche/documents/rc_com_pcchc_19940319_biblioteche-ecclesiastiche_it.html

Prado, Inês Virgínia. 2009. Direito ao (do) patrimônio cultural brasileiro. Belo Horizonte: Fórum.

Rabello, Sônia. 2009. O Estado na preservação de bens culturais: O tombamento. Ed. especial. Série Reedições do IPHAN. Rio de Janeiro: IPHAN.

Rodrigues, Francisco Luciano Lima. 2008. Patrimônio cultural - A propriedade dos bens culturais no Estado Democrático de Direito. Fortaleza: UNIFOR.

Rodrigues, José Eduardo Ramos. 2012. "Crimes contra o patrimônio cultural e o ordenamento urbano", em Estudos de direito do patrimônio cultural, José Eduardo Ramos Rodrigues e Marcos Paulo de Souza Miranda, 147-179. Belo Horizonte: Fórum. 
Silva, Fernando Fernandes. 2003. As cidades brasileiras e o patrimônio cultural da bumanidade. São Paulo: Ed. USP.

Soares, Inês Virgínia Prado. 2009. Direito ao (do) patrimônio cultural brasileiro. Belo Horizonte: Fórum.

UNESCO. 1954. Convenção sobre a proteção de bens culturais em caso de conflito armado. Acesso em 7 de janeiro de 2015. http://www.direitoshumanos.usp.br

UNESCO. 1964. Recomendação sobre medidas destinadas a proibir e impedir a exportação, a importação e a transferência de propriedade ilícita de bens culturais. Acesso em 27 de abril de 2014. http://unesdoc.unesco.org

UNESCO. 1970. Convenção relativa às medidas destinadas a proibir e impedir a exportação, a importação e a transferência de propriedade ilícita de bens cultuais. Acesso em 27 de abril de 2014. http://unesdoc.unesco.org

UNESCO. 1976. Recomendação sobre o intercâmbio internacional de bens culturais. Acesso em 27 de abril de 2014. http://unesdoc.unesco.org

UNESCO. 1978. Recomendação sobre a proteção dos bens culturais móveis. Acesso em 27 de abril de 2014. http://unesdoc.unesco.org

Vieira, Domingos. 1871-1874. Grande diccionario portuguez ou thesouro da lingua portugueza. 5 vol. Porto: E. Chardron e Bartholomeu H. de Moraes.

Para citar este texto:

Santos, Renata Ferreira dos y Alcenir Soares dos Reis. 2018. "O Patrimônio bibliográfico no Brasil: trajetória de leis, políticas e instrumentos de proteção legal”. Investigación Bibliotecológica: archivonomía, bibliotecología e información 32 (75): 223-259.

http://dx.doi.org/10.22201/iibi.24488321xe.2018.75.57970 